\title{
Decadal evolution of a very small heavily debris-covered glacier in an Alpine permafrost environment
}

\author{
M. CAPT,${ }^{1}$ J.-B. BOSSON, ${ }^{1}$ M. FISCHER,${ }^{2}$ N. MICHELETTI, ${ }^{1}$ C. LAMBIEL ${ }^{1}$ \\ ${ }^{1}$ Institute of Earth Surface Dynamics, University of Lausanne, Lausanne, Switzerland \\ ${ }^{2}$ Department of Geosciences, University of Fribourg, Fribourg, Switzerland \\ Correspondence: J.-B. Bosson <jeanbaptiste.bosson@gmail.com>
}

\begin{abstract}
Glacier response to climate forcing can be heterogeneous and complex, depending on glacier system characteristics. This article presents the decadal evolution of the Tsarmine Glacier (Swiss Alps), a very small and heavily debris-covered cirque glacier located in the Alpine periglacial belt. Archival aerial photogrammetry and autocorrelation of orthophotos were used to compute surface elevation, volume and geodetic mass changes, as well as horizontal displacement rates for several periods between 1967 and 2012. A GPR survey allowed us to investigate glacier thickness (15 $\mathrm{m}$ mean) and volume $\left(4 \times 10^{6} \mathrm{~m}^{3}\right)$ in 2015 and to anticipate its future evolution. Different dynamics occurred in recent decades because of the heterogeneous surface characteristics. The climate-sensitive upper debris-free zone contrasts with the progressively stagnant heavily debris-covered glacier tongue. Between 1967 and 2012, the glacier lost $1 / 3$ of its initial volume $\left(2 \times 10^{6} \mathrm{~m}^{3}\right)$. The average mass balance stabilised at $\sim-0.3 \mathrm{~m}$ w.e. $\mathrm{a}^{-1}$ since 1999 . Compared with other local glaciers, the Tsarmine Glacier shows a particular decadal behaviour both in time (divergence of mass balance since the 2000s) and space (inverted ablation pattern). This might be explained by the combined influence of debris cover, shadow, snow redistribution and permafrost conditions on this very small glacier.
\end{abstract}

KEYWORDS: climate change, debris-covered glaciers, glacier mass balance, mountain glaciers, permafrost

\section{INTRODUCTION}

Knowledge about the global response of the $>200000$ glaciers on Earth to climate change has considerably improved in recent years (Vaughan and others, 2013; Pfeffer and others, 2014), especially through large-scale modelling (e.g. Gardner and others, 2013; Radić and others, 2014; Huss and Hock, 2015). On a local scale, however, large uncertainties remain for individual glaciers because processes and glacial dynamics are implemented in a simplified manner in the models. Indeed, each glacier shows specific behaviour to some extent, influenced by local topoclimatic factors, glacier hypsometry or surface characteristics (Carturan and others, 2013a; Fischer and others, 2015). These particularities may generate non-linearities that complicate the response of glaciers to climate change (Paul and others, 2007; Scherler and others, 2011; Carrivick and others, 2015). Understanding of this local complexity and its integration in global approaches remain a major task (Huss, 2012; Huss and Fischer, 2016; Pellicciotti and others, 2015).

In high-relief environments, three characteristics can strongly influence the individual response of glaciers to climatic variations: (1) small glacier size, (2) debris cover on the ice and (3) permafrost conditions. These characteristics affect an increasing number of mountain glaciers with the current rise in the ELA (Benn and others, 2003; Vaughan and others, 2013). Indeed, shrinking glaciers are becoming smaller and thinner. Glacier melt is especially rapid in temperate environments and glaciers tend to be confined within the coldest areas of the Earth's surface (e.g. Huss, 2012; Huss and Hock, 2015). Moreover, because ice deformation is related to ice thickness, the dynamics of shrinking glaciers is decreasing (Paul and others, 2007) and their capacity to evacuate their sediment load is thus reducing. At the same time, deglaciation and permafrost degradation in the surrounding relief increase the debris supply. As a result, supraglacial debris covers are expanding on mountain glaciers (Carturan and others, 2013a; Kirkbride and Deline, 2013).

Very small glaciers $\left(<0.5 \mathrm{~km}^{2}\right)$ have a reduced motion (Haeberli, 1985; Benn and others, 2003; Paasche, 2012). Usually too thin to allow noticeable ice deformation, they are also weakly affected by basal processes. The production of meltwater and the shear stress acting on the glacier bed are both limited. In general, these glaciers react more rapidly to climatic variations (Jóhannesson and others, 1989; Kuhn, 1995; Colucci and Guglielmin, 2014). Due to the small altitudinal range, variations in the ELA of these glaciers rapidly change the proportion of accumulation and ablation areas, and strongly impact on glacier mass balance. On the other hand, the influence of the surrounding topography on small cirque glaciers can significantly attenuate their climate sensitivity (DeBeer and Sharp, 2009; Carturan and others, 2013b; Scotti and others, 2014). Accumulation and ablation anomalies occur in relation to the snow redistribution by avalanches, shadow effects or the presence of a debris cover. They can decouple the climatic control on mass-balance variations. Debris covers exceeding several decimetres in thickness are especially efficient thermal insulator layers and significantly reduce the ablation rate (Benn and others, 2003; Deline and others, 2012). Finally, permafrost conditions can strongly influence glacier dynamics. The thermal regime of the glacier can be cold or polythermal because of the surface and basal energy balance (Etzelmüller and 
Hagen, 2005; Cuffey and Paterson, 2010). Otherwise, repeated freeze/thaw cycles increase the sediment production in the surrounding relief (Deline and others, 2015) and the amount of debris deposited on the glacier surface. Ablation rate is then significantly reduced in these environments when the thickness of the debris cover is close to that of the permafrost active layer (i.e. seasonally thawing layer; Lilleøren and others, 2013). At the glacier margins, the deposition of the large amount of debris may induce the build-up of moraine dams (Benn and others, 2003; Iturrizaga, 2013). Complex glacier/permafrost interactions can also occur around the glacier (Ackert, 1998; Berthling and others, 2013). Thereby, the presence of cold ice, a moraine dam and/or a rock glacier commonly restrain the glacier's downward flow under permafrost conditions (Kirkbride and Deline, 2013). Consequently, very small heavily debris-covered glaciers located in permafrost environments often react with thickness variations rather than length changes.

Studies focusing on this type of glacier are relatively few and are led by geomorphological rather than glaciological questions. Mainly focused on glacier/permafrost interactions, research has characterised the internal structure (e.g. Reynard and others, 2003; Ribolini and others, 2010) and its relation to glacier dynamics or hydrology (e.g. Kneisel and Kääb, 2007; Pourrier and others, 2014; Seppi and others, 2015; Bosson and Lambiel, 2016). There have been fewer studies on the decadal behaviour of these glaciers and, at this timescale, their past and future evolution still remains largely unknown. This paper combines remote sensing and geophysical surveys to determine the response of a very small mountain glacier in the Swiss Alps to climate variations over the past five decades. Changes in surface elevation and ice dynamics were assessed for successive observation periods by comparing high-precision DEMs with aerial images. Geodetic glacier mass balance was computed for each period. In addition, a GPR survey was carried out to determine the current ice thickness distribution and glacier volume. Finally, we compare the decadal evolution of the Tsarmine Glacier with other local glaciers to uncover potential particularities in the behaviour of very small and heavily debris-covered cirque glaciers located in permafrost environments.

\section{STUDY SITE AND CLIMATIC CONTEXT}

\subsection{The Tsarmine Glacier system}

The Tsarmine Glacier system is located in the Arolla valley in Switzerland $\left(46^{\circ} 03^{\prime} \mathrm{N}, 7^{\circ} 31^{\prime} \mathrm{E} ; 0.49 \mathrm{~km}^{2} ; 2600-3070 \mathrm{~m}\right.$ a.s.I.; Fig. 1). Detailed geomorphological analysis and mapping of this complex assemblage of interacting landforms can be found in Lambiel and others (2004), Micheletti and others (2015a) and Bosson and Lambiel (2016). This very small cirque glacier $\left(0.25 \mathrm{~km}^{2}\right.$ in 2015) occupies the foot of the 400-600 m high rock walls of the Grande Dent de Veisivi and Blanche de Perroc. Until the 1980s, a north-facing ice apron covered the latter (Delaloye, 2008). Nowadays, the rock walls are affected by strong rockfall activity. For instance, a major rockfall occurred near the top of the west face of the Grande Dent de Veisivi in September 2015, following an extraordinarily warm summer. The presence of water in the scarp coming from ice melt indicated the existence of permafrost conditions in the area.
Situated at the shade-dominated base of Blanche de Perroc between 3070 and $2920 \mathrm{~m}$ a.s.l., the uppermost debris-free part of the glacier receives little solar radiation (zone 1; Fig. 1c). Avalanching enhances snow accumulation, leading to a cone-like surface morphology. Below, down to $\sim 2830 \mathrm{~m}$ a.s.l., a discontinuous and relatively thin (millimetres to decimetres) layer of debris covers the glacier today (zone 2a; Fig. 1c). This zone showed continuous variations in surface conditions (debris-free vs. debris-covered) in recent decades, but overall the debris cover progressively extended upward through time. Downslope, a thick (decimetres to few metres) and continuous debris mantle has been present since at least 1967 (zone 2b; Fig. 1c). The supraglacial layer is made up of coarse-grained angular deposits of rockfalls, indicating their passive transfer on the glacier. Ice outcrops become very rare and are related to thermokarstic erosion. Arcuate round ridges are visible on the surface (Fig. 1c). The debris layer, which thickens downslope, masks the lower limits of the glacier. It was detected with electrical resistivity tomography (ERT) near $2715 \mathrm{~m}$ a. s.I. (Bosson and Lambiel, 2016). These results also allowed distinguishing debris-covered dead ice (zone 3; Fig. 1c) from ice-free debris located around a proglacial lake (zone 5 and 6). Downslope, a large gullied moraine dam delimits the Tsarmine system. Accumulated during the Holocene glacial pulses (Ivy-Ochs and others, 2009), it illustrates that this fluctuating glacier probably always contained large amounts of debris, produced by the erosion of the surrounding rock walls composed of fractured gneiss. The presence of an active rock glacier at the northern margin of the Tsarmine system points to the local occurrence of permafrost conditions (zone 4; Fig. 1c). The presence of push moraines indicates a deformation by the readvance of Tsarmine Glacier during the Little Ice Age (LIA; Lambiel and others, 2004). Like other similar systems (Bosson and others, 2015; Micheletti and others, 2015a), Tsarmine is disconnected from downslope sediment transfer systems because of the presence of the moraine dam and the rock glacier, the relatively weak slope angle $\left(17^{\circ}\right.$ of mean slope for the longitudinal profile between the top of the glacier and the top of the moraine dam), the reduced magnitude of sediment transfer processes and the absence of a proglacial meltwater stream.

Bosson and Lambiel (2016) quantified the surface kinematics of the Tsarmine system between 2011 and 2014 with repeated dGPS measurements. The results highlighted the existence of different dynamic behaviours at annual and seasonal timescales between zones $2 b, 3,4$ and 5 . The mean horizontal surface displacement was $60 \mathrm{~cm} \mathrm{a}^{-1}$ and the mean vertical change rate $-17 \mathrm{~cm} \mathrm{a}^{-1}$ in the debriscovered glacier zone (zone 2b). Surface dynamics were weaker elsewhere: $\sim 20 \mathrm{~cm} \mathrm{a}^{-1}$ of downslope creep in the marginal rock glacier (zone 4 ), $\sim 15 \mathrm{~cm} \mathrm{a}^{-1}$ of surface lowering in the proglacial dead ice body (zone 3 ) and discontinuous, very slow movements in ice-free debris (zone 5).

\subsection{Climatic context}

The Tsarmine Glacier system is located in a dry intra-Alpine valley. Topography acts as a barrier for wet air masses and reduces annual precipitation rates considerably. Combining meteorological data collected by Hydro-exploitation SA between 2001 and 2013 at $2000 \mathrm{~m}$ a.s.I. on the valley floor with monthly lapse rates estimated locally (between 0.54 and $0.63^{\circ} \mathrm{C}(100 \mathrm{~m})^{-1}$ with an annual mean of $0.59^{\circ} \mathrm{C}$ 

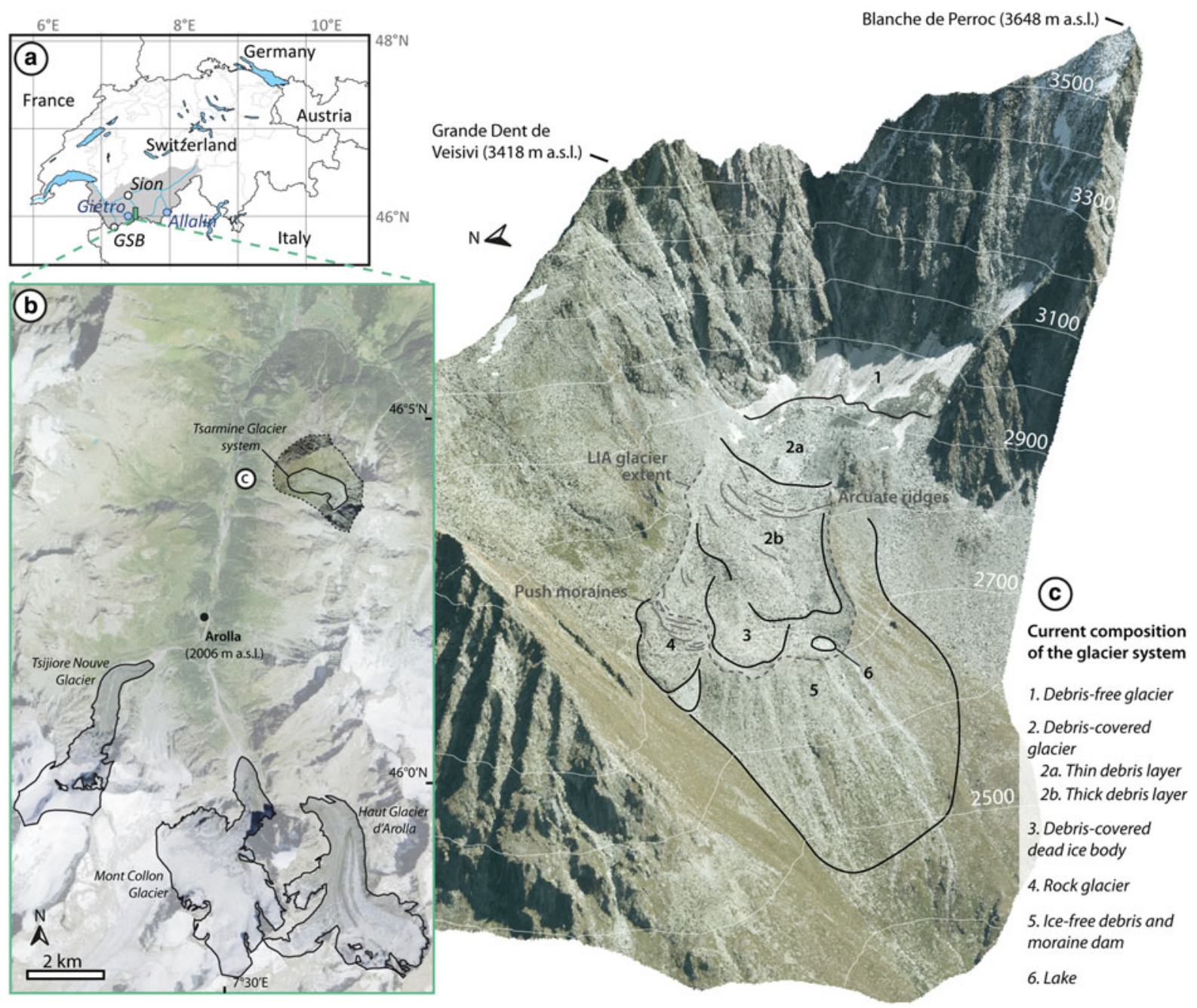

Fig. 1. Geographic setting and main components of the Tsarmine Glacier system: (a) location of the Arolla valley. (b) Location of the Tsarmine Glacier system and of the three larger valley glaciers referred to in this study (aerial image: Landsat 25 1990-94; Swisstopo). (c) Main components of the Tsarmine Glacier system (aerial image: orthophoto 2012).

$(100 \mathrm{~m})^{-1}$ at these elevations, Bouët, 1985), the mean annual air temperature at $2800 \mathrm{~m}$ a.s.I. is currently $\sim-0.8^{\circ} \mathrm{C}$. Mean annual precipitation measured on the valley floor between 2001 and 2013 is $200 \mathrm{~mm}$.

Figure 2 shows the evolution of the regional climate (south- western Valais) between 1930 and 2015. Homogenised monthly data for Sion (482 m a.s.I.; 24 km distance from Tsarmine, Fig. 1a), and Col du Grand St Bernard (GSB) $(2472 \mathrm{~m}$ a.s.l.; $34 \mathrm{~km}$ distance from Tsarmine, Fig. 1a) weather stations were used (MeteoSwiss). To highlight the variations of the most important climatic parameters on the glacier, the mean deviation of annual and summer (July-September in this high-mountain environment) air temperatures and annual and winter precipitation (OctoberMay) relating to the 1961-1990 normal climate period were calculated for both stations. Between the 1950s and the mid-1980s, annual temperatures fluctuated around or slightly below the climatic norm. Subsequently, a clear warming trend set in: temperatures exceeded the norm by at least $1^{\circ} \mathrm{C}$ and continued to progressively increase until 2012. Summer temperatures behaved similarly, but the rapid increase had already started some years before, around 1980. Annual and winter precipitation showed larger fluctuations. Both were generally below the climatic norm before 1980 and after 2000 while the 20 years in between were wetter.

\section{METHODS}

The methodology of this study was based upon: (1) the creation of DEMs using archival digital photogrammetry; (2) use of these DEMs to derive surface elevation changes and orthorectified imagery; (3) calculation of mass balance from the surface elevation changes; (4) analysis of surface displacement rates through image correlation applied to the orthorectified images; (5) application of GPR to quantify the spatial ice thickness distribution and volume.

\subsection{Creation of DEMs using archival digital photogrammetry}

DEMs were created by applying archival digital photogrammetry (Walstra and others, 2004; Chandler and others, 2007) to historical aerial photographs held by the Swiss Federal Office of Topography (Swisstopo) for the period 19672005. Additionally, we used aerial images acquired in 2012 by the commercial company Flotron AG (Table 1). DEM creation from aerial orthoimagery is described in 


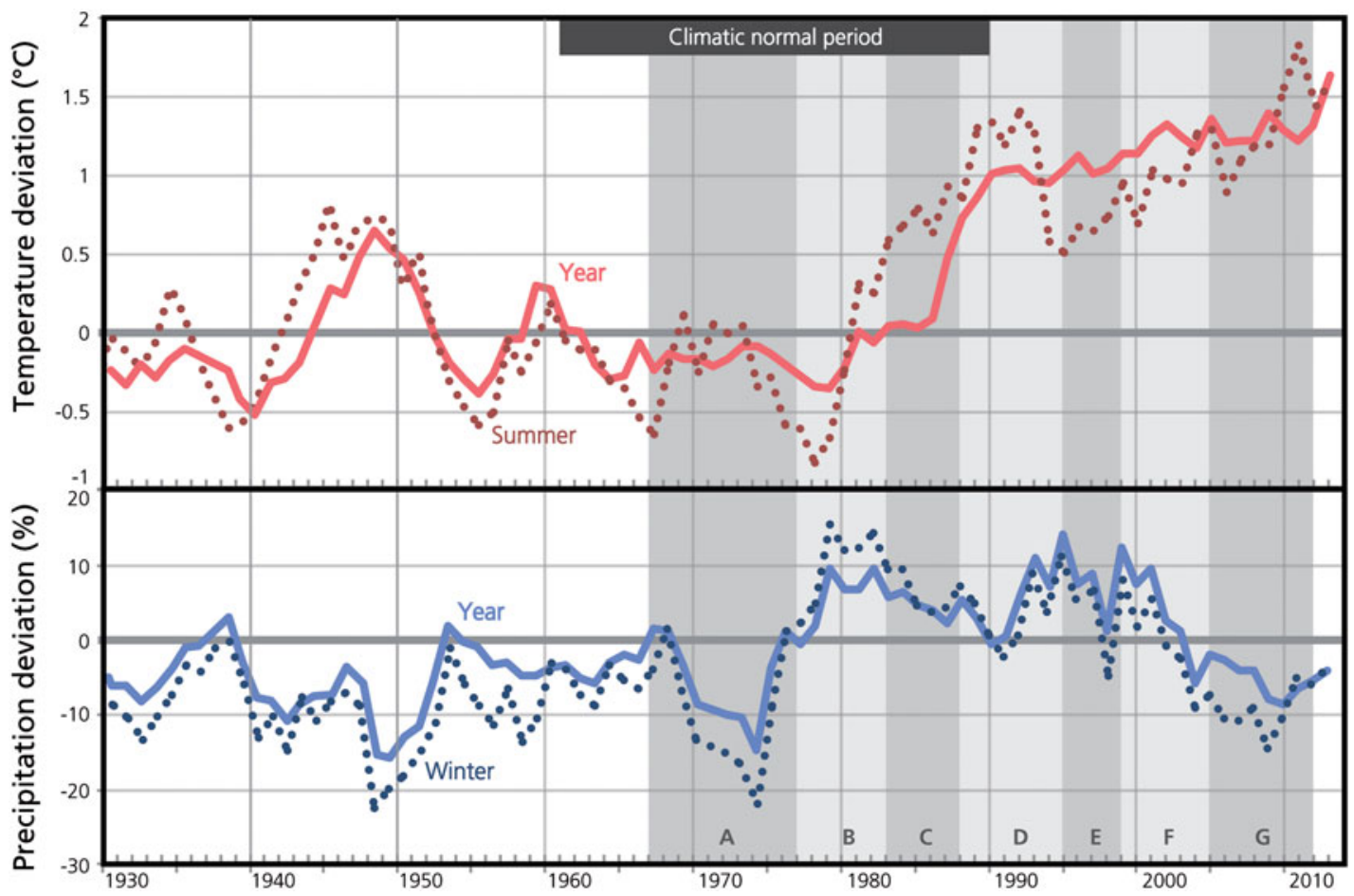

Fig. 2. Evolution of annual (solid curve) and summer (dotted curve; means of monthly values from July to September) air temperature and annual (solid curve) and winter (dotted curve; sums of monthly values from October to May) precipitation in the south-western Valais between 1950 and 2014. Based on homogenised monthly series of MeteoSwiss, the mean deviations of data from Sion and Grand St Bernard (GSB) stations (location in Fig. 1a) from the 1961 to 1990 climatic normal period have been computed. Only the 5-year running means are represented.

detail by Micheletti and others (2015b), and therefore only summarised here. Digital aerial photogrammetry requires a number of Ground Control Points (GCPs) for the photogrammetric restitution. A network of GCPs was established using a Leica System 500 dGPS during a field campaign in 2012. These points must be stable through the whole observation period, well distributed over the area of interest and easy to identify on the images. Given varying image quality and contrast, it was not always possible to retrace all GCPs locations with high accuracy and confidence. It was crucial to obtain as many GCPs as possible, to always have adequate observations well distributed over the (varying) extent covered by the photographs. Consequently, GCPs employed (and unused) varied between pairs of images. Survey data were post-processed and corrected using data from an automated GNSS Network for Switzerland (AGNES) to a vertical and horizontal precision better than $\pm 0.05 \mathrm{~m}$. Image processing for DEM creation was performed using ERDAS IMAGINE Leica Photogrammetry Suite. It involved three main steps: (1) definition of the internal orientation of the camera using camera calibration certificates available for each image pair; (2) after manually identifying the GCPs, estimating the exterior orientation using a conventional bundle adjustment; (3) application of automatic stereomatching algorithms to identify homologous points on image pairs and so to compute ground coordinates. The resulting point clouds were used to compute $1 \mathrm{~m}$ resolution DEMs for each period by applying a kriging interpolation in ArcGIS 10. DEMs were derived for eight dates between 1967 and 2012 (Table 1).

Table 1. Characteristics of the aerial imagery, DEM accuracy and precision estimates using dGPS survey data (Micheletti and others, 2015b), mean snowline altitude and accumulation area ratio at each date

\begin{tabular}{|c|c|c|c|c|c|c|}
\hline Date of aerial imagery & Scale & Emulsion & $\begin{array}{l}\text { DEM mean } \\
\text { error } \\
\mathrm{m}\end{array}$ & $\begin{array}{c}\text { Standard deviation } \\
\text { of errors } \\
\mathrm{m}\end{array}$ & $\begin{array}{c}\text { Mean snowline } \\
\text { altitude } \\
\text { m a.s.l. }\end{array}$ & $\begin{array}{c}\text { Accumulation } \\
\text { area ratio }\end{array}$ \\
\hline 28 September 1967 & $1: 15700$ & BW & 0.315 & 0.765 & 2900 & 0.40 \\
\hline 08 September 1977 & $1: 20900$ & BW & 0.504 & 0.82 & 2870 & 0.47 \\
\hline 07 September 1983 & $1: 20900$ & BW & 0.281 & 0.953 & 2885 & 0.41 \\
\hline 10 August 1988 & $1: 20900$ & BW & 0.296 & 0.644 & 2920 & 0.22 \\
\hline 02 September 1999 & $1: 28000$ & RGB & 0.493 & 0.827 & 2930 & 0.12 \\
\hline 17 August 2005 & $1: 24800$ & RGB & 0.453 & 0.998 & 2900 & 0.31 \\
\hline 20 September 2012 & $1: 5200$ & RGB-NIR & 0.356 & 0.462 & 2910 & 0.21 \\
\hline
\end{tabular}

BW, black and white; RGB, red, green, blue (colour); NIR, near infrared.

The two values in brackets have to be considered carefully because fresh snow hampered the identification of the real snowline in 1995 . 


\subsection{Calculation of surface elevation changes}

To obtain surface elevation changes, DEMs of different years were differenced to obtain DEMs of Difference (DoDs). At this stage, areas of ineffective photogrammetric restitution became visible; these corresponded to zones where, because of low image texture, shadow effects, excessive steepness or occlusion, stereomatching algorithms failed and only a few low quality points were used to represent the topography. As a consequence, unrealistic elevation differences were found, especially in the upper part of the glacier. To avoid unreliable estimates, these areas were identified and removed from the analysis.

To distinguish real topographical changes from noise associated with random error in the derived surface elevation changes, a standard error propagation procedure was employed (Lane and others, 2003). First, the quality of each DEM was assessed with dGPS data from unused GCPs by computing the difference in elevation with DEM values in the respective locations (Table 1 ). The precision of each DEM, estimated as the standard deviation of these errors, was used to quantify limits of detection for each DoD, following Lane and others (2003). The significance level was set to $90 \%$ in order to obtain a greater confidence that values in the DoD actually corresponded to real topographical changes. The limits of detection for each pair of DEMs are given in Table 2. Only differences larger than these values were employed to compute surface elevation and volumetric changes $(\Delta V)$ for individual observation periods.

\subsection{Calculation of average mass balance}

Area-averaged specific geodetic mass-balance rates $\dot{B}$ $\left(\mathrm{m}\right.$ w.e $\mathrm{a}^{-1}$ ) were computed for each observation period with:

$$
\dot{B}=\frac{\Delta V \cdot f \Delta v}{A \cdot \Delta t}
$$

where $A$ is the glacier area $\left(\mathrm{m}^{2}\right)$, and $\Delta t$ the length of each observation period. Equation (1) includes a conversion factor $f \Delta v$, set to 0.85 , which corresponds to a density of volume change of $850 \pm 60 \mathrm{~kg} \mathrm{~m}^{-3}$. Such a value is commonly used (e.g. Fischer and others, 2015) and is recommended for periods $>5$ years, for a study site composed by a firn area and for volume changes significantly different

Table 2. Limits of detection of elevation changes for each pair of images (both absolute values and normalized per year) with a confidence level of $90 \%$ computed following the approach by Lane and others (2003)

\begin{tabular}{lcc}
\hline Pair of images & $\begin{array}{c}\text { Limits of detection } \\
90 \%\end{array}$ & $\begin{array}{c}\text { Limits of detection } \\
\pm \mathrm{m}\end{array}$ \\
& $\begin{array}{c}90 \% \\
\pm \mathrm{m} \mathrm{a}^{-1}\end{array}$ \\
\hline $1967-77$ & 1.839 & 0.18 \\
$1977-83$ & 2.04 & 0.34 \\
$1983-88$ & 1.862 & 0.37 \\
$1988-95$ & 1.623 & 0.23 \\
$1995-99$ & 1.833 & 0.45 \\
$1999-2005$ & 2.126 & 0.35 \\
$2005-12$ & 1.804 & 0.25 \\
$1967-2012$ & 1.466 & \\
\hline
\end{tabular}

See Micheletti and others (2015b) for details. from zero (Huss, 2013). ERT (Bosson and Lambiel, 2016) and GPR results allow us to quantify the current glacier area to $252000 \mathrm{~m}^{2}$ (zones 1, 2a, 2b; Fig. 1c). This value was always used to calculate the glacier's average mass balance because the presence of extensive debris cover has hampered a clear determination of downslope glacier boundaries in recent decades. Weak variations of debriscovered glacier areas observed elsewhere at a decadal timescale support this approach (e.g. Deline, 2005; Schmidt and Nüsser, 2009; Benn and others, 2012). The evolution of the specific geodetic mass balance rates between 1967 and 2012 were compared with the mean glaciological mass balances from Huss and others (2015) for two nearby glaciers (Giétro and Allalin, 5.5 and $9.7 \mathrm{~km}^{2}$, at 12 and $30 \mathrm{~km}$ distance from Tsarmine; Fig. 1a) and to the decadal extrapolated mass balance means of glaciers in the European Alps (Huss, 2012). In addition, we compared the surface elevation and mass changes of the Tsarmine Glacier since the 1980s with those of the neighbouring Tsijiore Nouve Glacier, Mont Collon Glacier (also known as Bas Glacier d'Arolla) and Haut Glacier d'Arolla (Fig. 1b) using the data provided by Fischer and others (2015).

\subsection{Quantification of horizontal surface displacement rates and aerial imagery analysis}

Archival aerial photogrammetry also allowed orthorectification of the aerial photographs, which were then used to quantify horizontal surface displacement rates within the observation periods. For this purpose we used the $7 D$ software (Vacher and others, 1999). Based on image autocorrelation, this software identifies the same features on images of two different dates based upon correlation of image grey-scale values. The comparison of images generates vectors illustrating the value of the pixel displacement, which, by using image resolution, can be expressed in $\mathrm{m} \mathrm{a}^{-1}$. The quality and the quantity of identified vectors depended on quality and characteristics of the source images themselves and was impaired considerably by the presence of shadow or fresh snow, and by poor image contrast. Thus, it was not always possible to quantify horizontal surface displacements for some areas (especially the upper half of the glacier) or during some periods. We only present results obtained within the Tsarmine Glacier system. Horizontal surface displacement rates detected in neighbouring stable areas were below the limit of detection $\left(<0.1 \mathrm{~m} \mathrm{a}^{-1}\right)$. Otherwise, movements of some large boulders were manually tracked on the photographs. The horizontal velocity values obtained with image autocorrelation and feature tracking for the most recent period are close to those measured between 2011 and 2014 by dGPS (Bosson and Lambiel, 2016).

Mean snowline altitude and accumulation area ratio (AAR) were calculated for each period based on the orthorectified aerial photographs to investigate the evolution of the accumulation area of the Tsarmine Glacier over the past few decades (Table 1). These values provide interesting information on the recent evolution of the Tsarmine Glacier. Nevertheless, their interpretation requires care because the identification of annual accumulation of snow and ice is challenging on aerial images. Moreover, snow accumulation on very small glaciers can be very patchy and variable from year to year (Huss, 2010). Aerial photographs were taken a bit too late (7 October) in 1995 and a fresh snow cover 
hinders the identification of the end of ablation season snowline.

\subsection{Measuring glacier thickness and volume}

GPR data for Tsarmine Glacier were acquired on 10 March 2015 with a Malå Geoscience ProEx System consisting of a control unit mounted in a backpack, a portable monitor and a $100 \mathrm{MHz}$ rough terrain antenna with a constant offset of $2.2 \mathrm{~m}$. Taking four measurements $\mathrm{s}^{-1}$, the antenna was pulled across the glacier at walking speed. For each measurement, 728 samples were recorded within a time window of $550 \mathrm{~ns}$. The measurement (trace) positions were acquired with a conventional GPS receiver connected to the monitor. Horizontal accuracy in the position of the GPR-derived glacier thickness data is $\pm 5 \mathrm{~m}$. Individual radar profiles were collected along a total length of $\sim 3500 \mathrm{~m}$ and covered the entire debris-free and debris-covered parts of the glacier (1, 2a, 2b; Fig. 1c), at high-spatial resolution.

A series of standard processing steps (e.g. Sold and others, 2013) were applied to the GPR raw data using Reflexw 2D data analysis (Sandmeier Scientific Software). These included a spatial interpolation to a constant $1 \mathrm{~m}$ spacing of traces to account for variations in the walking speed, a frequency bandpass filtering to reduce noise, a background removal, a gain function to compensate for radar wave power loss with depth and a fk (Stolt) migration to account for omnidirectional reflections of the signal and correct geometrical irregularities. Only unambiguous reflection horizons of the glacier bed were picked and stored as $x_{-}, y_{-}$, thickness data. For time/depth conversion, a constant radar propagation velocity in ice of $0.167 \mathrm{~m} \mathrm{~ns}^{-1}$ was assumed (Hubbard and Glasser, 2005). Following Fischer (2009), we expect the accuracy of measured glacier thicknesses to be in the order of $5-10 \%$ of the measured values. Uncertainty may be caused by the measurement system itself, but is primarily attributed to changes of the signal velocity below the glacier surface, e.g. within the debris-cover layer. The measured glacier thickness data were imported in ArcGIS to derive the spatial distribution of ice thickness and glacier volume. To avoid and/or reduce linear interpolation artefacts, the measured point density was reduced to $1 \%$ of the originally recorded data by only considering every hundredth measurement (dots of measured glacier thickness in Fig. 7). Zero glacier thickness was assigned to the glacier outline prior to the spatial interpolation of point thickness data. Because different algorithms have been shown to produce significantly varying results (Fischer and Kuhn, 2013), topo to raster, kriging and inverse distance weighting (IDW) techniques were applied to create $10 \mathrm{~m} \times 10 \mathrm{~m}$ grids of the 2015 glacier thickness, and their results were subsequently compared with each other.

\section{RESULTS}

\subsection{Movement and elevation changes in the proglacial zones}

The marginal zones of the Tsarmine system (3, 4, 5, 6; Fig. 1c) are not analysed in detail here. Their comprehensive analyses at both decadal and annual/seasonal timescales were carried out by Micheletti and others (2015a) and Bosson and Lambiel (2016). Elevation changes of the proglacial zones between 1967 and 2012 revealed a surface lowering of up to $20 \mathrm{~m}$ that can be attributed to three main processes: (1) ice melt in the debris-covered dead ice body and the rooting zone of the rock glacier (zones 3 and 4; Fig. 3h), (2) thermokarstic erosion of the ice by lake formation near the glacier front (zone 6; Fig. 3h) and (3) gullying of the outer side of the moraine dam (zone 5; Fig. 3h). Except for the development of a proglacial lake between 1983 and 1999 (Figs 3c-e), the magnitude of these processes was generally too weak to be systematically observable over the short term. Horizontal surface displacement rates (Fig. 4) showed a recent acceleration of the rock glacier, where velocities reached $70 \mathrm{~cm} \mathrm{a}^{-1}$ in the rooting zone between 1999 and 2005 (zone 4). Discontinuous, slow movements were reconstructed for the proglacial area (zones 3 and 5; Fig. 4). They show that the delineation of glacier boundaries in debris-covered environments can be challenging. For instance, the dead ice zone was almost completely stagnant between the 1967-1988 and 1995-1999 periods and was flowing during the 1999-2005 period. Still, the distinction of this zone from the upslope glacier (zone 1, $2 \mathrm{a}, 2 \mathrm{~b})$ relies on their different dynamic behaviour on both decadal (Fig. 4) and seasonal timescales (Bosson and Lambiel, 2016). The few movements reconstructed at these timescales for the area surrounding the lake indicate that most of the remnant ice present in this zone melted during recent decades (Fig. 3).

\subsection{Elevation changes and geodetic mass balances of the Tsarmine Glacier}

There were clear differences in the elevation changes between the upper part of the glacier, composed of the debris-free zone, the middle part covered by a thin debris mantle (zones 1, 2a; Fig. 3), and the downslope heavily debris-covered one (zone 2b). From 1967 to 1977, a lowering of $\sim 0.18-0.4 \mathrm{~m} \mathrm{a}^{-1}$ was found in the heavily debriscovered part and contrasted with elevation gain up-glacier (Fig. 3a). Between 1977 and 1983, changes were more homogeneous over the whole glacier and a significant positive elevation change up to $1 \mathrm{~m} \mathrm{a}^{-1}$ affected its central part (Fig. 3a). Between 1983 and 1995 (Figs 3c, d), surface lowering was observed in the upper half, but a discontinuous elevation increase affected the heavily debris-covered zone and migrated progressively downslope. This is clearly noticeable between 1983 and 1988 for instance (Fig. 3c), when a significant volume loss of $820000 \mathrm{~m}^{3}$ in the upper part contrasts with a positive volume change of $140000 \mathrm{~m}^{3}$ in the lower part. Since 1995, elevation loss has been dominant, but the lowering rate decreased after 1999 in zone 1 (Figs 3e-g).

For the entire period (1967-2012) (Fig. 3h), the volume change was negative, with a loss of $2 \times 10^{6} \mathrm{~m}^{3}$ over 45 years. Whereas the volume losses mainly affected the upslope part (with up to $30 \mathrm{~m}$ of elevation loss in zone 2a) and secondarily the glacier front, the middle part, covered by a thick layer of debris, actually gained in volume $(\sim 260$ $\left.000 \mathrm{~m}^{3}\right)$. This corresponds to a maximum positive elevation change of $15 \mathrm{~m}$. These clear heterogeneous spatial patterns are also observable on a central longitudinal flowline transect (Fig. 5a) and have changed the glacier surface topography: whereas in 1967 the surface was convex for the debris-free zone and slightly concave for the heavily debris-covered part, the surface of the glacier was generally convex in the debris-covered portion and slightly concave in the debrisfree zone by 2012 (Fig. 5b). 


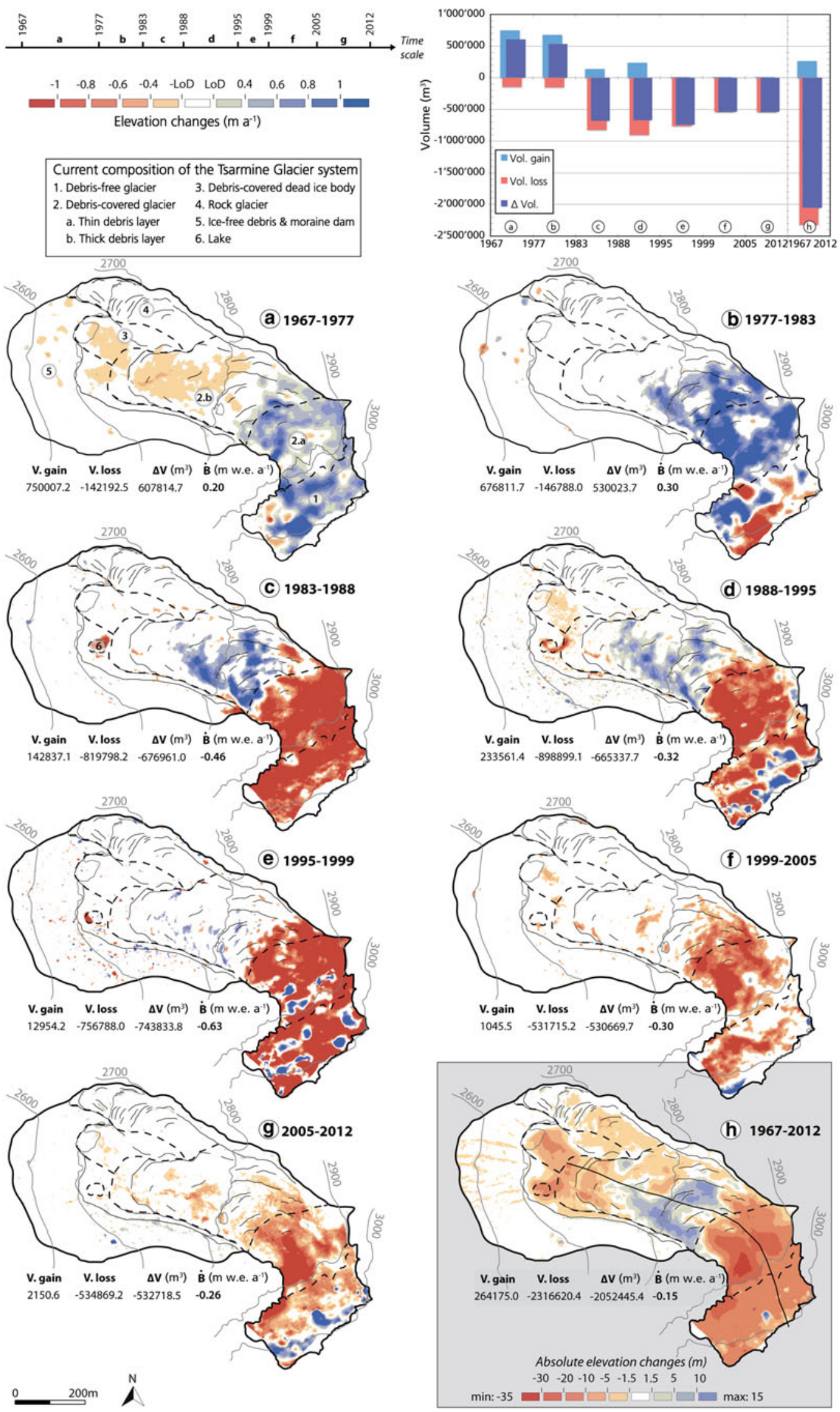

Fig. 3. Surface elevation, volume and average geodetic mass balance changes of Tsarmine Glacier for seven different periods between 1967 and 2012, derived from archival aerial photogrammetry. The longitudinal transect in the synthesis map (h) is referred to in Fig. 5, 10. The limit of detection (LoD) values are listed in Table 2. 


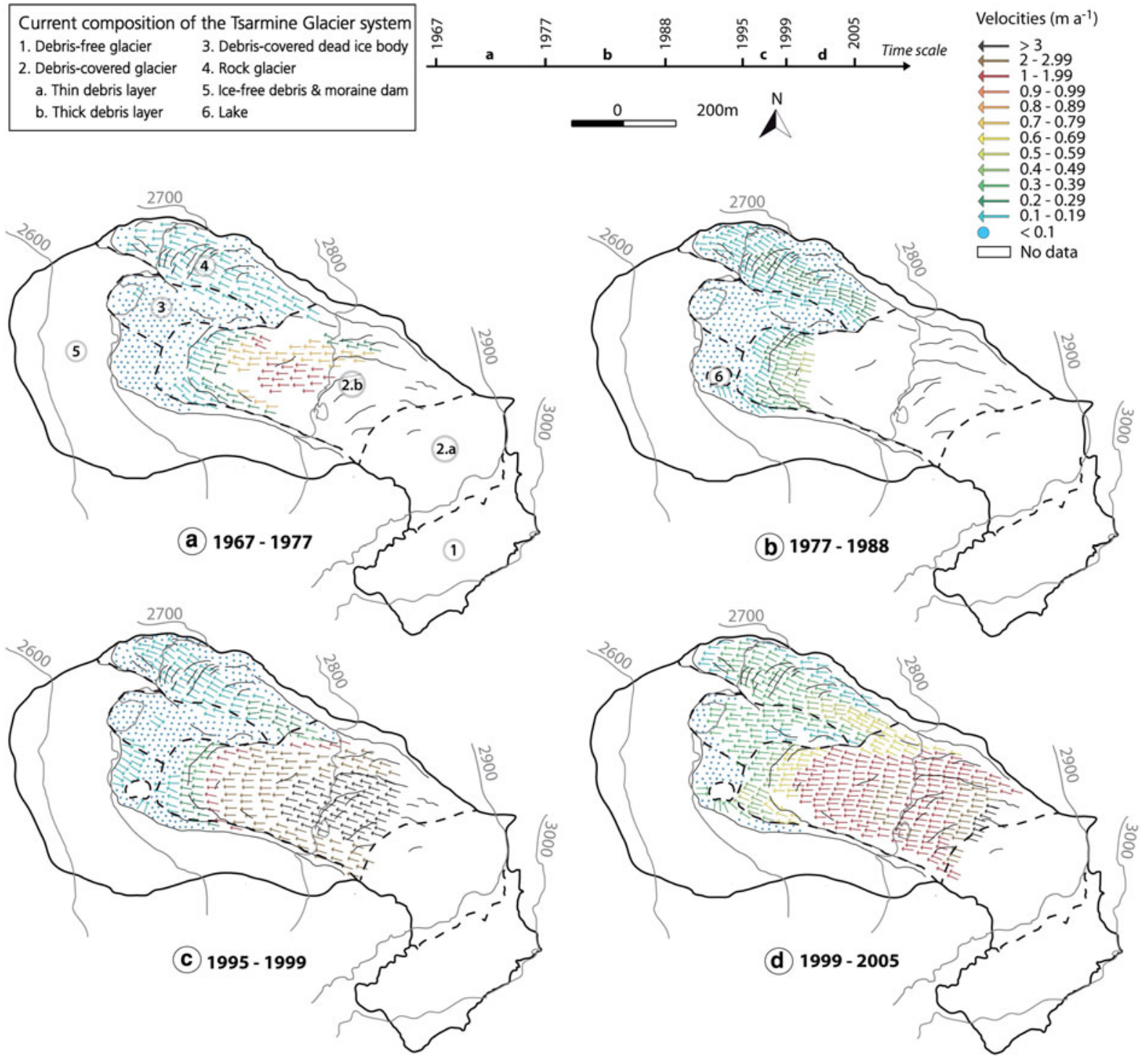

Fig. 4. Horizontal surface displacement rates for different parts of the Tsarmine Glacier system between 1967 and 2005, obtained with 7D software.

Between 1967 and 2012, two stages of resulting mass changes were recorded for the Tsarmine Glacier. It went from a positive mass-balance context, with rates of $0.20 \mathrm{~m}$ w.e. $\mathrm{a}^{-1}$ for the period 1967-1977 (Fig. 3a), and $0.30 \mathrm{~m} \mathrm{w.e.} \mathrm{a}^{-1}$ between 1977 and 1983 (Fig. 3b), to a negative massbalance context with most negative values between 1995 and 1999 (-0.62 m w.e. $\mathrm{a}^{-1}$; Fig. 3e). However, mass balances for the 2000s were less negative again $(-0.26 \mathrm{~m}$ w.e. $\mathrm{a}^{-1}$ between 1999 and 2005 and $-0.30 \mathrm{~m}$ w.e. $\mathrm{a}^{-1}$ between 2005 and 2012, respectively; Figs 3f, g). Over the entire period 1967-2012, there was a negative average mass balance of $-0.15 \mathrm{~m}$ w.e. $\mathrm{a}^{-1}$.

\subsection{Horizontal surface displacement rates of the Tsarmine Glacier and aerial imagery analysis}

The horizontal surface displacements shown in Figures 4, 5b illustrate significant spatial and temporal variations. The period 1967-1977 revealed horizontal surface displacements of $\sim 1-2 \mathrm{~m} \mathrm{a}^{-1}$, which decreased down-glacier to $\sim 0.1-0.2 \mathrm{~m}$ $\mathrm{a}^{-1}$ (Fig. 4a). For the following decade, values between 0.1 and $0.5 \mathrm{~m} \mathrm{a}^{-1}$ were obtained over the debris-covered glacier snout (Fig. 4b). In the late 1990s, horizontal surface displacements increased to up to $1 \mathrm{~m} \mathrm{a}^{-1}$ for this area (Fig. 4c). Meanwhile, displacement rates exceeded $3 \mathrm{~m} \mathrm{a}^{-1}$ in the central up-glacier zone and decreased towards the margins. Except for the glacier terminus, a velocity decrease affected all the debris-covered part in the early 2000s (Figs 4d, 5b).

Two main outcomes were obtained from tracking large boulders (Fig. 6): (1) horizontal surface displacements decreased down-glacier and (2) the periods with highest displacement rates varied spatially. Glacier surface motion in the central upslope zone reached its maximum between 1977 and 1983, with values $>7 \mathrm{~m} \mathrm{a}^{-1}$ (block No. 1). At the glacier snout (block No. 7) the displacements were much lower and highest velocities were reached between 1999 and $2005\left(0.7 \mathrm{~m} \mathrm{a}^{-1}\right)$. Thus, from upslope to downslope, there was an apparent attenuation of the maximum surface displacement rates and a temporal delay of the maximum values over time. This shows the progressive translation down-glacier of a wave of maximum superficial displacement rates. Between 2005 and 2012, the motion of Tsarmine Glacier decreased, as shown by the displacement rates of all boulders. 


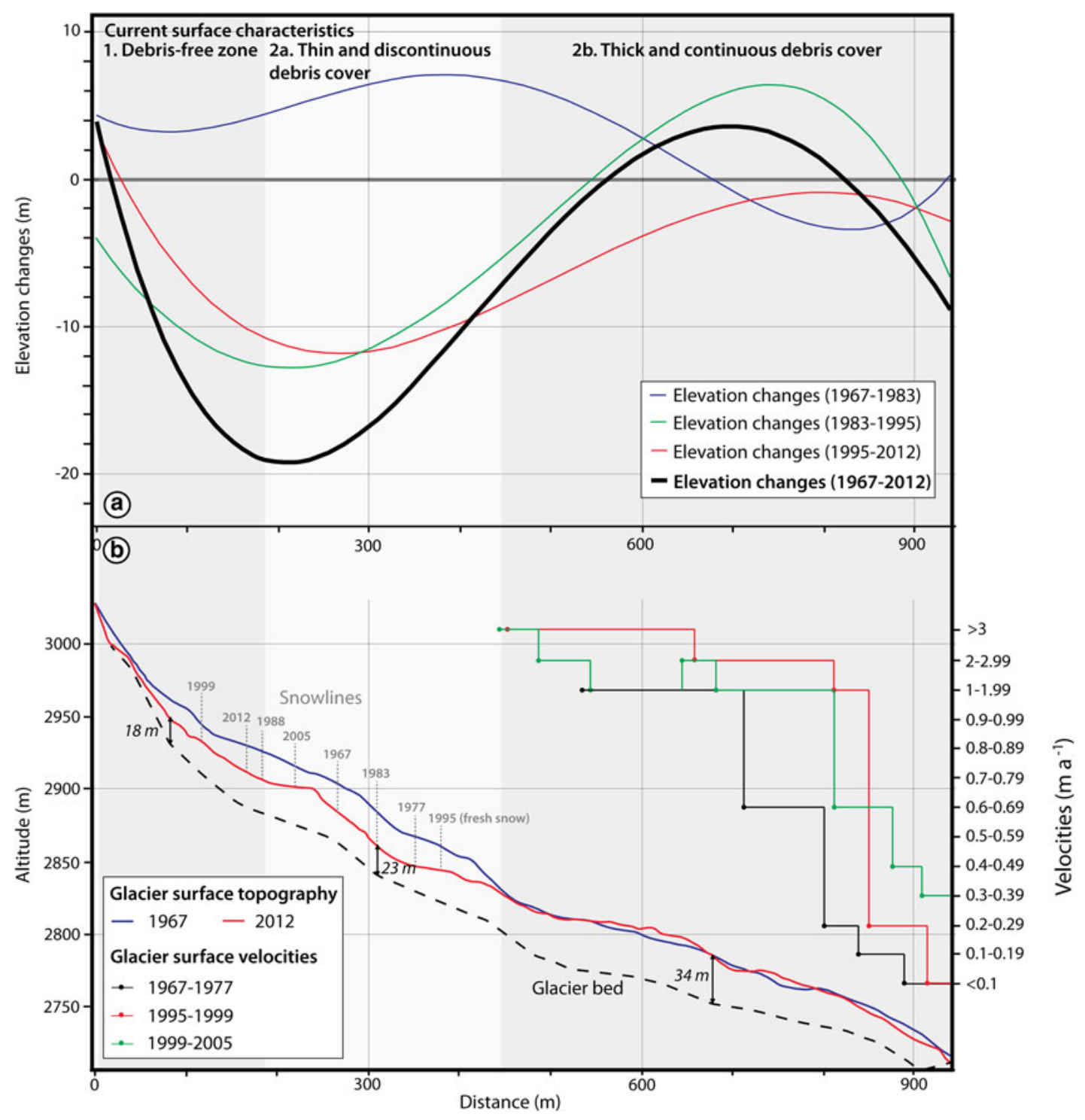

Fig. 5. (a) Surface elevation changes between 1967 and 1983 (blue), 1983 -1995 (green), 1995-2012 (red) and 1967-2012 (bold black) along a longitudinal transect of Tsarmine Glacier, visible in Figure 3h. The graphs were computed with the 'interpolate line' tool in ArcGIS 10. (b) Longitudinal elevation profiles in 1967 (blue) and 2012 (red). The dashed black curve shows the glacier bed derived from ground penetrating radar data. The snowline altitude along the longitudinal transect, detected from aerial imagery, is reported at each date. On the right-hand side, the horizontal displacement rates along the longitudinal transect are derived from the image autocorrelation (Fig. 4).

Reconstructions of estimated mean snowline altitudes and AARs from aerial photographs showed that the relative proportion of the accumulation area of the Tsarmine Glacier generally decreased in recent decades (Table 1; Fig. 5b). More than the upper third of the glacier was snow covered in 1967, 1977 and 1983. Without considering the unrepresentative values of 1995, the accumulation area was above $2900 \mathrm{~m}$ a.s.l. and corresponded to $<30 \%$ of the glacier surface in 1988, 1999, 2005 and 2012.

\subsection{Current ice thickness and volume of Tsarmine Glacier}

The 2015 GPR survey (Figs 5b, 7) revealed a maximum ice thickness of $36 \mathrm{~m}$, recorded in the lower heavily debriscovered part. There, cross-section profiles showed a $U$ shaped glacier bed with the steeper thickness gradients towards the left LIA moraine (Fig. 7a). Upslope, in the middle part covered by a thinner debris layer, the glacier thickness decreased and was particularly shallower towards the lateral margins. The glacier bed here has a gentle $\mathrm{V}$ shaped profile along a cross section, with thickest measured values of slightly $>20 \mathrm{~m}$ for a very narrow central part (Fig. 7b). Up-glacier a trough-like bed was found, with glacier thicknesses $>15 \mathrm{~m}$ in its centre.

The mean interpolated glacier thickness was $\sim 15 \mathrm{~m}$ (Table 3). Due to the comparatively high relative spatial density and the complete coverage of measured GPR profiles, the different interpolation algorithms applied to the measured point data returned very similar results, both for the spatial glacier thickness distribution and mean glacier thickness. The present (2015) bed topography and volume of Tsarmine Glacier, which amounted to $4.05 \pm 0.4 \times 10^{6} \mathrm{~m}^{3}$, can be derived if the interpolated glacier thickness grids are subtracted from the latest highresolution DEM of 2012 and the 2012-2015 surface elevation changes are considered in the calculation. The volume change exceeded $2 \times 10^{6} \mathrm{~m}^{3}$ between 1967 and 2012. The glacier thereby lost $1 / 3$ of its initial volume in the past 45 years. 


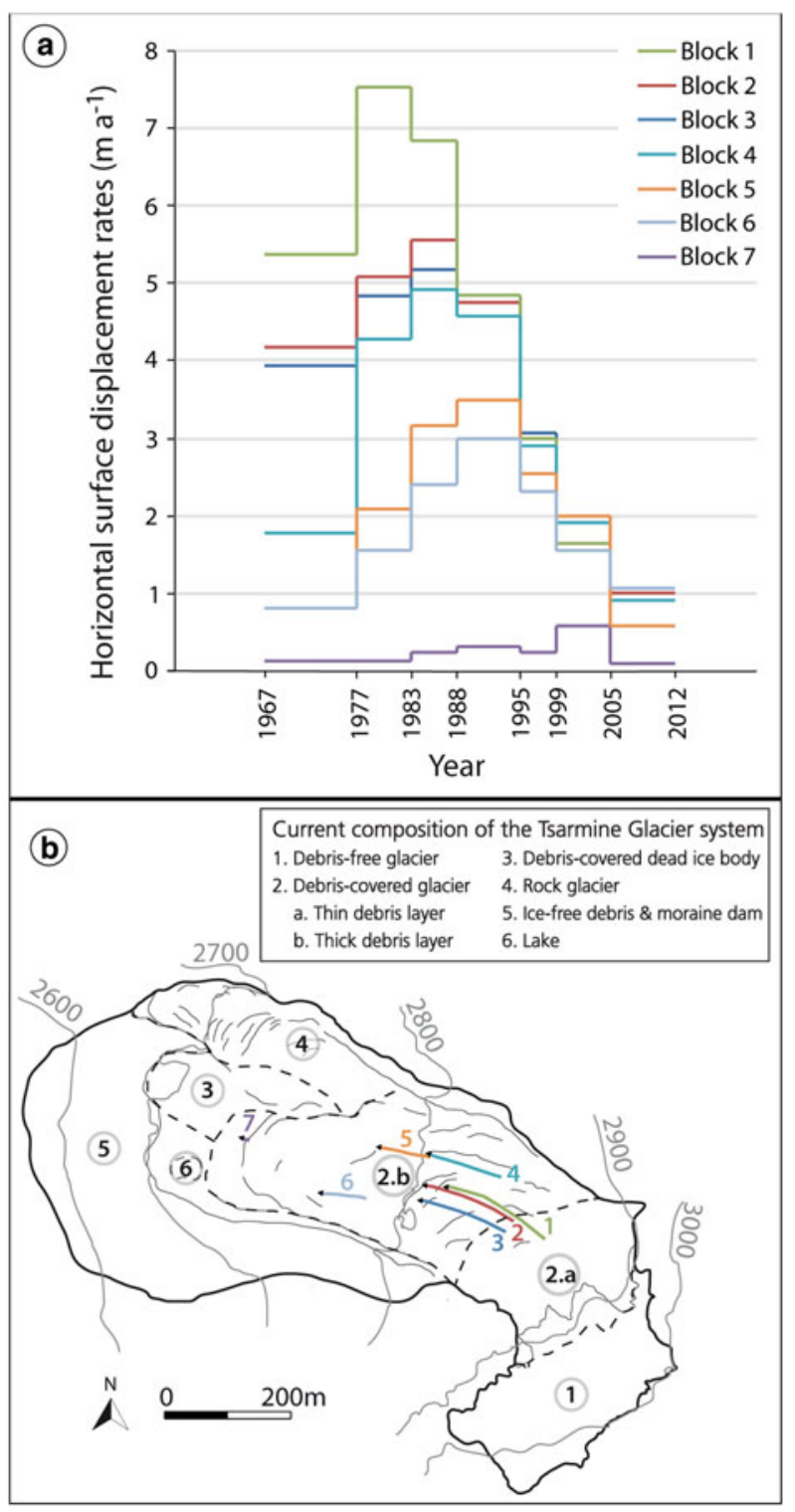

Fig. 6. (a) Horizontal surface displacement rates obtained by tracking some large boulders on the debris-covered glacier and (b) their successive position on the glacier.

\section{DISCUSSION}

\subsection{Main controls on decadal elevation changes of Tsarmine Glacier}

From the spatial distribution of the surface elevation changes (Fig. 3), it is possible to infer that the most dynamic part of the glacier is the upper half, including the debris-free zone (1) and the zone covered by a relatively thin and discontinuous debris layer (2a). Volume changes were marked here and related to snow and ice accumulation and ablation, ice fluxes and, to a lesser extent, debris deposition. They were likely to be strongly controlled by air temperature, especially during summer, as reported in other studies (Arendt and others, 2009; Diolaiuti and others, 2012; Thibert and others, 2013). The periods of mass gain correspond to the coldest years (Figs 2, 3a, b). Significantly higher summer temperatures resulted in rapid surface lowering (Figs $3 \mathrm{C}-\mathrm{g}$ ). Thus, the temperature-driven summer mass balance is a primary control on the annual mass balance in debris-free zones as observed for other glaciers (e.g. Huss and others, 2015).
Because of the consistency of air temperature on the regional scale (Begert and others, 2005), the decadal evolution of surface elevation changes in the upper part of Tsarmine is very representative for the behaviour of Alpine glaciers during this period (Deline and others, 2012; Huss, 2012; Vaughan and others, 2013; Huss, and others, 2015). However, winter snow can modify and enhance these effects. The greatest mass gain (Fig. 3b) occurred during a period when winter precipitation generally exceeded the long-term average (Fig. 2). Since the 2000s, lower winter precipitation may have reduced snow cover at the start of summer, leading to an earlier transition to ice exposure, lower albedo and enhanced melt (e.g. DeBeer and Sharp, 2009). The most rapid and spatially homogeneous volume loss occurred between 1983 and 1999 (>650 $000 \mathrm{~m}^{3}$; Figs 3c, d). Three main reasons, visible on aerial photographs, can explain the deceleration of lowering rates since 1999 while air temperature continued to increase: (1) the snow and ice accumulated from the 1960s to the mid-1980s has largely and rapidly melted in subsequent warmer years, as observed elsewhere in the Alps (Paul and others, 2007); (2) the increasing emergence and deposition of debris in this zone has reduced the ablation rate; (3), the concomitant confinement of the accumulation area at the shaded and avalanche-fed backwalls' foot has limited the sensitivity to climate (Table 1; Fig. 5b).

The influence of climatic variations on the elevation changes of the debris-covered glacier tongue (zone 2b) is not so obvious. Elevation changes were slightly negative on the tongue between 1967 and 1977, while they were positive upslope (Fig. 3a). Conversely, they were positive or close to zero between 1983 and 1999 in zone 2b, when elevation in the upper zone decreased rapidly (Figs 3c-e). From 1967 to 2012, the centre of the down-glacier parts presented positive surface elevation changes, whereas the frontal zone was lowered by up to $10 \mathrm{~m}$ (Fig. $3 \mathrm{~h}$ ). Two processes may interact to explain this effect. First, the increased thickness of the debris layer down-glacier will slow down melt rates because ablation rate and the superficial debris thickness are negatively correlated (e.g. Benn and others, 2012). It induces an inversion of the ablation pattern down-glacier, as revealed by the surface elevation changes along the longitudinal profile since 1967 (Fig. 5a). The maximum melt rate then occurs at the transition between debris-covered and debris-free, just below the ELA (Kellerer-Pirklbauer and others, 2008; Shea and others, 2015), where ice loss generally exceeded 20 m between 1967 and 2012 (zone 2a; Fig. 3h). Second, there was probably a progressive down-glacier migration of the mass accumulated upslope between the 1960s and the mid-1980s (Figs 3a-e; e.g. Carrivick and others, 2015). The downward propagation of a wave of maximum but decreasing surface displacement over time supports this assumption (Fig. 6a). Similar observations were reported by Thomson and others (2000) for a larger debris-covered glacier (Miage Glacier; area of $11 \mathrm{~km}^{2}$ ) over the 20th century. They illustrate the delayed and attenuated effects of climatic variations on mass changes of heavily debris-covered tongues: upslope surface elevation changes are dynamically transferred but attenuated towards the glacier front. Because of their reduced ablation rates, heavily debris-covered glacier tongues are less affected than debris-free glaciers by negative mass-balance perturbations, such as downwasting or frontal retreat (Thomson and others, 2000; Scherler and others, 2011; Haeberli and 


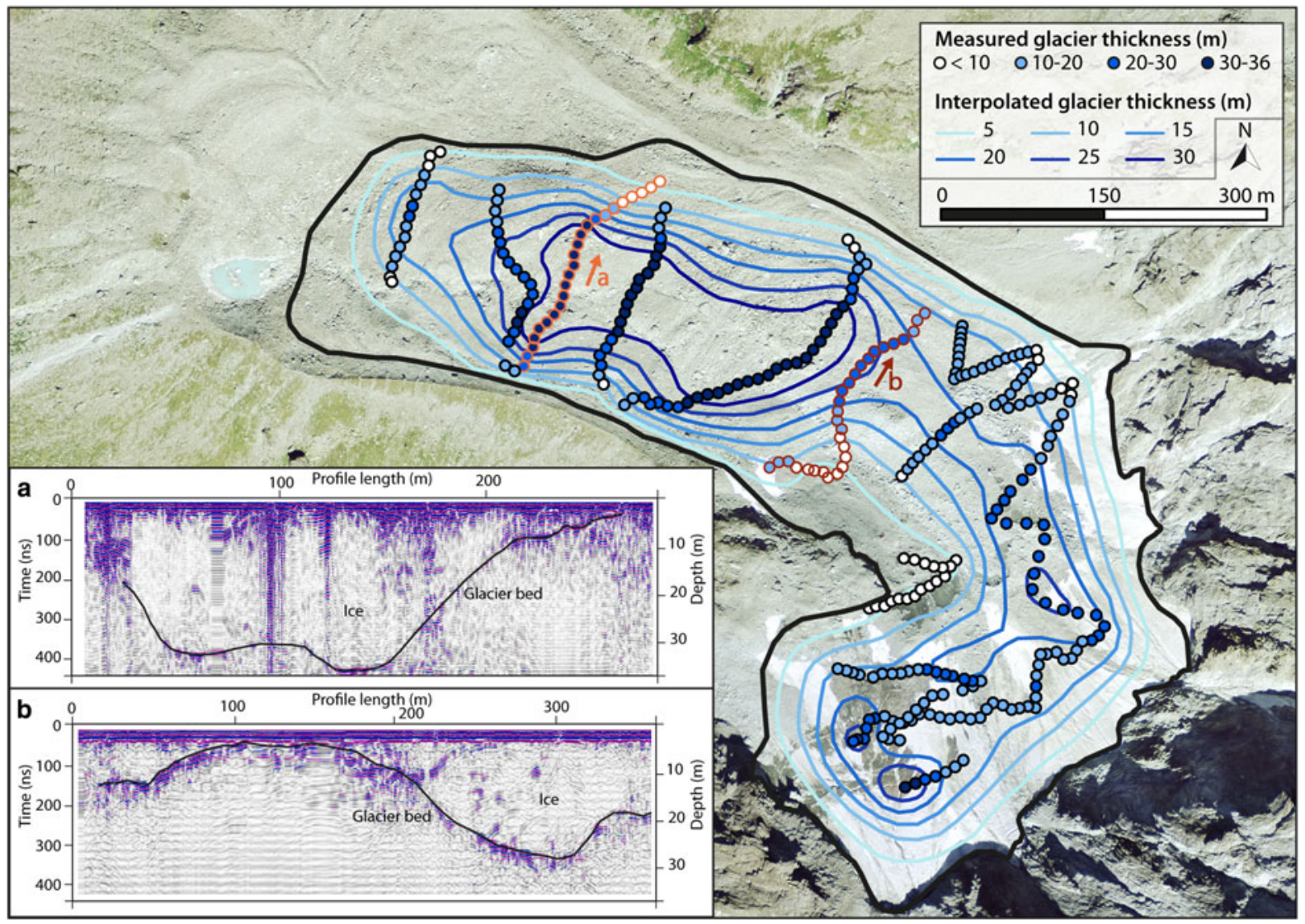

Fig. 7. Measured ice thickness and interpolated ice thickness contours obtained from March 2015 GPR data, as well as two examples of radargrams showing the glacier bed with black lines (aerial image: Swiss image level 2 2013; Swisstopo).

others, 2013). Conversely and as observed for Tsarmine, significant positive mass-balance perturbations can lead to an increase in surface elevation of the debris-covered glacier snouts.

\subsection{Surface displacement rates and associated dynamics}

The analysis of surface displacement rates (Figs 4,6) highlights four main characteristics of the decadal dynamics of Tsarmine Glacier. (1) Due to the propagation of the snow and ice accumulated from the 1960s to the mid-1980s, a kinematic wave of maximum displacement rates with progressively decreasing intensity migrated down-glacier (Fig. 6; Thomson and others, 2000; Cuffey and Paterson, 2010). (2) Surface displacement rates decrease significantly towards the glacier terminus (Figs 5b, 6), which can be explained by the reduced driving stress in this area (Cuffey and Paterson, 2010). This effect may be enhanced by the

Table 3. Mean $\left(h_{\text {mean }}\right)$ and maximum $\left(h_{\max }\right)$ glacier thickness derived from GPR point measurements and different interpolation algorithms

\begin{tabular}{lccr}
\hline & $\begin{array}{c}h_{\text {mean }} \\
\mathrm{m}\end{array}$ & $\begin{array}{c}h_{\max } \\
\mathrm{m}\end{array}$ & $\begin{array}{c}\text { Std dev. } \\
\mathrm{m}\end{array}$ \\
\hline GPR point measurements & 19.5 & 35.8 & 8.6 \\
Topo to raster & 15.1 & 39.2 & 9.6 \\
Kriging & 15.2 & 36 & 10.7 \\
IDW & 15.5 & 36 & 10.7 \\
& & & \\
\hline
\end{tabular}

downstream accumulation of sediments. Increasing the compressive flow, it often contributes to restraining the glacier motion (Kirkbride and Deline, 2013). Hence the uplift of the central part of the glacier is probably both due to an advective mass transfer and associated compression (Gudmundsson and others, 2000; Kellerer-Pirklbauer and others, 2008). The formation of arcuate superficial ridges around the uplift zone in recent decades is very likely related to this compressive stress increase (Fig. 3h). (3) The glacier motion generally tends to decelerate over time, as observed elsewhere in the Alps since the 1980s in the context of negative mass balances (Paul and others, 2007). There are multiple causes of this reduction in dynamics. Several metres of ice have been lost in the upper half and frontal glacier zone of Tsarmine since 1967 and, except for the central zone of the heavily debris-covered part, it is now mostly thinner than $25 \mathrm{~m}$ (Fig. 7). Moreover, the glacier surface is flattening, as revealed by its current linear or even concave profile (Fig. 5b). Both processes lead to a decrease in driving stress (Benn and others, 2012; Carrivick and others, 2015). Finally, snow and ice accumulation on Tsarmine Glacier have been limited and discontinuous since 1983, reducing the mass turnover and thus glacier dynamics (Paul and others, 2007). The overall decrease of the glacier motion contrasts with the acceleration of the rock glacier and dead ice zones between 1999 and 2005 (Fig. 4). Accelerations of similar landforms were also observed in the Alps (e.g. Delaloye and other, 2008). They were especially related to the increase of the permafrost temperature, the melt of ground ice and the increased presence of ground water induced by the 2003 heatwave. (4) The 
spatially rather homogeneous motion between 1995 and 2005 (Figs 4c, d) points to the domination of an en masse flow. Even if ice and may be bed deformation can also be active, it indicates the occurrence of basal sliding (Mayer and others, 2006; Copland and others, 2009). Hence, even though this glacier may be polythermal because of the surrounding permafrost conditions, a large portion of the basal ice likely has a temperate thermal regime, as indicated by its basal slip (Bingham and others, 2008). Similar results and interpretations were proposed from dGPS monitoring data (Bosson and Lambiel, 2016).

\subsection{A particular behaviour?}

Before 2000, the average geodetic mass balance of Tsarmine Glacier was consistent with the average glaciological mass balance of Giétro and Allalin glaciers (Huss and others, 2015) and with the extrapolated decadal mean of glaciers in the European Alps (Huss, 2012; Fig. 8). Except in comparison with the negative 1967-1977 anomaly for Giétro Glacier, the mass balance of Tsarmine Glacier shows both magnitude and temporal variations comparable with the other larger glaciers. It illustrates the homogenous control of regional climate on glaciers during this period. The computed mass balance of Tsarmine between 1988 and 1999 has to be considered with care. Indeed, fresh autumnal snow is observable in the upper zone on the aerial image of 1995 and integrated in the calculation. Thus, the mass balances between 1988-1995 (-0.32 m w.e. $\left.\mathrm{a}^{-1}\right)$ and 1995$1999\left(-0.63 \mathrm{~m}\right.$ w.e. $\left.\mathrm{a}^{-1}\right)$ are likely under- and overestimated and the real values are probably closer to those obtained for Giétro and Allalin glaciers. The period 2003-2012 appears to be the one with strongest mass losses for the Swiss glaciers for at least the last century (Huss, and others, 2015). However, this remarkably negative trend does not affect the Tsarmine mass balance, which stabilised at $\sim-0.3 \mathrm{~m}$ w.e. $\mathrm{a}^{-1}$ after 1999 (Fig. 8). This particular behaviour is not observable on other (very) small debris-free Alpine glaciers. For instance, the mass balances of Pizol (Huss, 2010) and Sarennes (Thibert and others, 2013) glaciers were three times more negative $\left(<-1 \mathrm{~m}\right.$ w.e. $\left.\mathrm{a}^{-1}\right)$ in recent years compared with Tsarmine. On a larger timescale, while Tsarmine lost 1/3 of its initial volume between 1967 and 2012; this

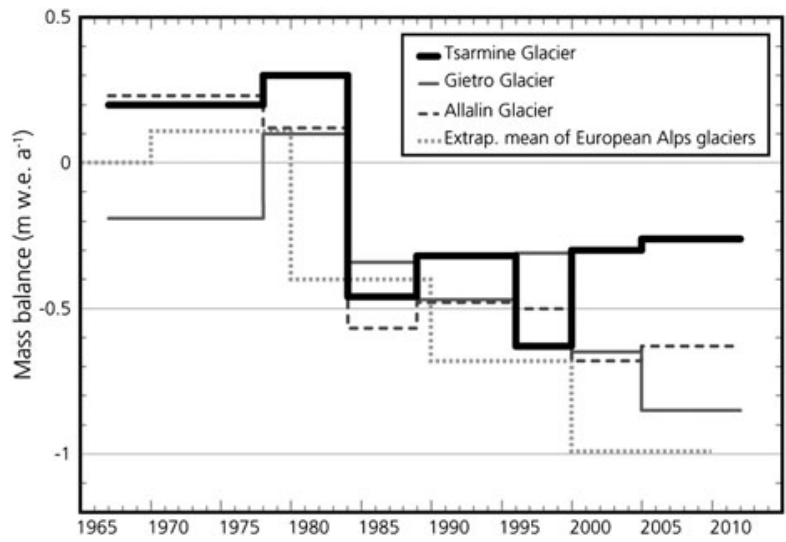

Fig. 8. Average geodetic mass balance of Tsarmine Glacier, average glaciological mass balance of Giétro and Allalin glaciers (location on Fig. 1a, Huss and others, 2015) and extrapolated decadal mean of the glaciers of the European Alps (Huss, 2012). value exceeded 68\% at Pizol between 1973 and 2006 (Huss, 2010). The progressive shrinking of the accumulation area in a north-facing shaded and avalanche-fed niche and the concomitant extension of the debris cover explain this peculiar variation in the Tsarmine Glacier mass balance since 1999. It highlights the recent decrease of the control of regional climate on this glacier once most of the snow/ ice accumulated during the 1960 s to mid-1980s had melted. This consequence of the increasing influence of topography and debris cover supports results found in other studies that analysed the behaviour of some small cirque glaciers in the final stage of glaciers vanishing (e.g. López-Moreno and others, 2006; DeBeer and Sharp, 2009; Carturan and others, 2013b; Carrivick and others, 2015). It contrasts with the dynamics recently undergone by climatically-driven (very) small bare-ice mountain glaciers (e.g. Huss, 2010; Thibert and others, 2013; LópezMoreno and others, 2015).

Comparing glacier surface elevation changes of Tsarmine since the 1980s with those of the nearby larger valley glaciers also reveals a particular spatial pattern for Tsarmine (Fig. 9). While the three large glaciers showed strongest lowering towards their terminus, Tsarmine Glacier lost most within its upper third. This highlights the importance of air temperature and thus altitudinal gradients for large glaciers. As very small cirque glaciers have a limited altitudinal gradient, other processes can superimpose on the effects of altitudinal temperature gradients. The decadal elevation changes of Tsarmine Glacier rather illustrate the influence of the delayed and attenuated mass transfer from the upper debris-free part to the debris-covered part and the debris cover thickening down-glacier. Interestingly, the snout of Tsijiore Nouve Glacier was also covered by a several decimetre thick debris layer in recent decades (e.g. Small, 1983 ) and is significantly less exposed to solar radiation than the Tsarmine snout (2.5 times smaller mean solar radiation; Fig. 9). However, up to $50 \mathrm{~m}$ of surface lowering occurred at the Tsijiore Nouve tongue since 1988. There, the presence of a thick debris cover and a weak exposure to solar radiation are thereby not sufficient to prevent rapid ice melt. The Tsarmine Glacier snout is located $300 \mathrm{~m}$ above the one of Tsijiore Nouve and within the discontinuous permafrost belt. The neighbouring rock glaciers show that ground ice can be preserved from noticeable melt under a several metre thick superficial debris layer (Lambiel and others, 2004; Bosson and Lambiel, 2016). Therefore, (1) the sheltering of a large portion of the glacier under a heavy debris mantle and (2) its confinement in a zone where air and ground temperatures are lower than for the other glaciers explain why the average mass balance since the 1980s is up to two times less negative for Tsarmine Glacier $\left(-0.5 \mathrm{~m}\right.$ w.e. $\left.\mathrm{a}^{-1}\right)$ compared with the three larger systems ( -0.58 to $-1.15 \mathrm{~m}$ w.e. $\mathrm{a}^{-1}$; Fig. 9). On a larger scale, it is also less negative than the average of glaciers in the European Alps from 1980 to $2000\left(-0.69 \mathrm{~m} \mathrm{w.e.}^{-1}\right.$; computed from decadal means of Huss, 2012; Fig. 8).

Projections of climate change for the next few decades suggest continued increase of air temperature (Collins and others, 2013). The observed varying patterns of elevation changes since 1983 are expected to sustain and govern the future evolution of Tsarmine Glacier. Negative mass balance stabilised between 1999 and 2012 and the mean lowering rates of $0.5,0.7$ and $0.2 \mathrm{~m} \mathrm{a}^{-1}$ were computed for the zones 1, 2a and 2b. In Figure 10, we extrapolate these 

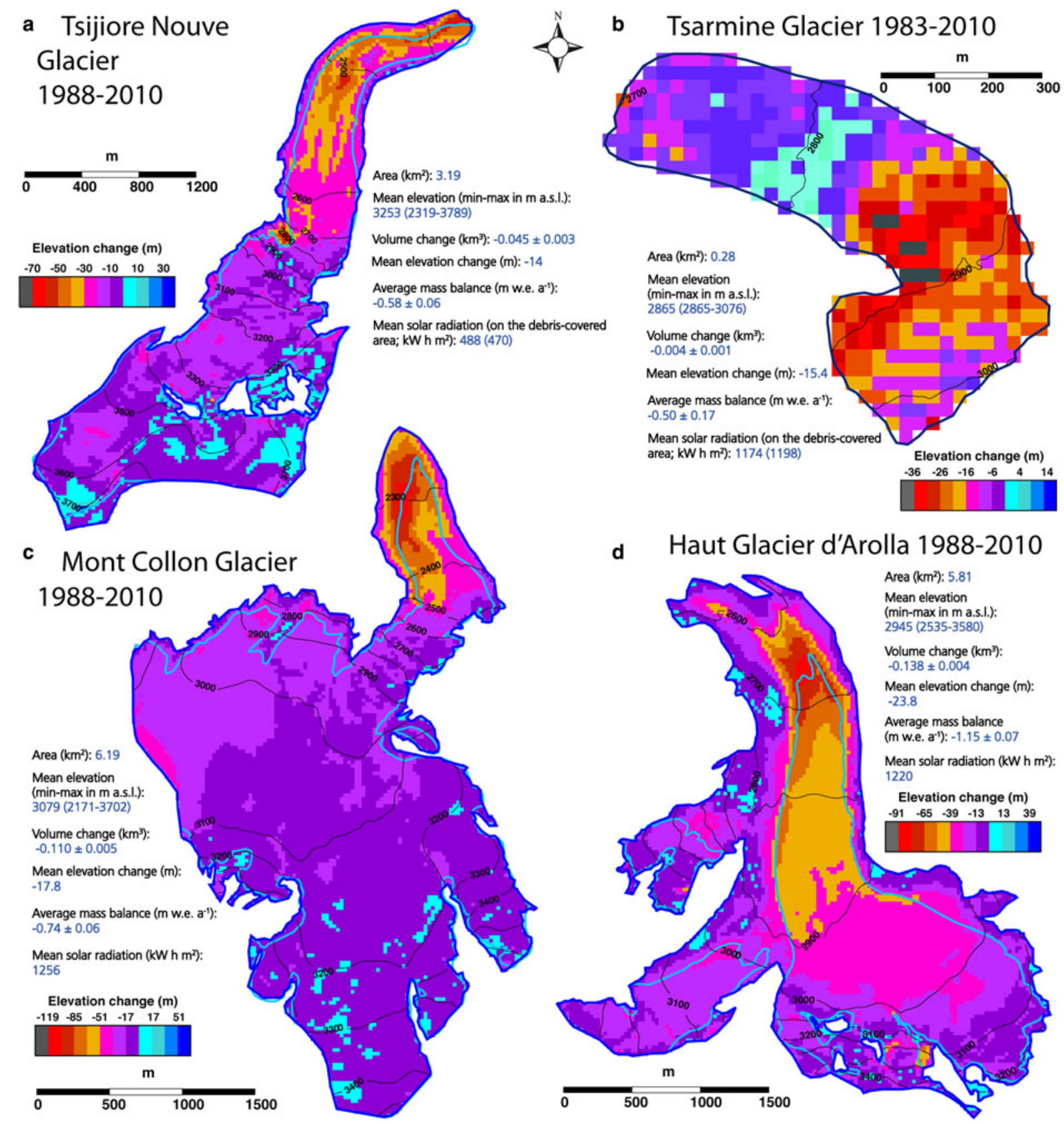

Fig. 9. Spatial distribution of elevation changes within the digital glacier outlines from the 1973 (dark blue) and the 2010 (light blue) Swiss Glacier Inventories (Müller and others, 1976; Fischer and others, 2014), derived by Fischer and others (2015) through a comparison of the DHM25 Level 1 DEMs from the 1980s with the 2010 swissALTI ${ }^{3 D}$ DEMs for (a) Tsijiore Nouve Glacier, (b) Tsarmine Glacier (location on Fig. 1a), (c) Mont Collon Glacier and (d) Haut Glacier d'Arolla. Mean area solar radiation was computed with ArcGis Spatial Analyst tool on the 2010 swissALTI ${ }^{3 \mathrm{D}}$ DEMs and according to the 2010 glacier extents (Fischer and others, 2014).

rates, taking into account the known ice thickness. In the upper half of the glacier, the lowering exceeded $10 \mathrm{~m}$ in the past 30 years, roughly corresponding to the remaining glacier thickness in 2015 (Figs 5b, 7). This rapid thinning particularly affects the transition zone between debris-free and heavily debris-covered zones and could cause the disintegration of the Tsarmine Glacier into two entities, as evoked for other heavily debris-covered systems (Benn and others, 2012; Shea and others, 2015). In contrast, the uppermost debris-free part appears a bit less sensitive to the air temperature increase because of the influence of topography on snow accumulation and solar radiation. The control of air temperature tends to decrease in this shaded avalanche-fed area, as observed since 1999 (Fig. 3). Conversely, the control of winter precipitation can increase here in the next few decades (Carturan and others, 2013b; Scotti and others, 2014). Sheltered in its proximal niche, this thinning glacier zone may progressively become an inactive and debriscovered ice patch (Serrano and others, 2011), as the input of debris on the glacier surface is likely to increase in the next few decades (Deline and others, 2015). Finally, this zone could evolve toward a talus slope (Gomez and others, 2003). In the lower half, the glacier thickness exceeds $30 \mathrm{~m}$ (Fig. 7). Here, the ice melt could take more than 100 years if the mean lowering rates of $0.2 \mathrm{ma}^{-1}$ observed over the past decade remain constant in the future. Several studies mention the recent transformation of similar heavily debris-covered glacier tongues into rock 


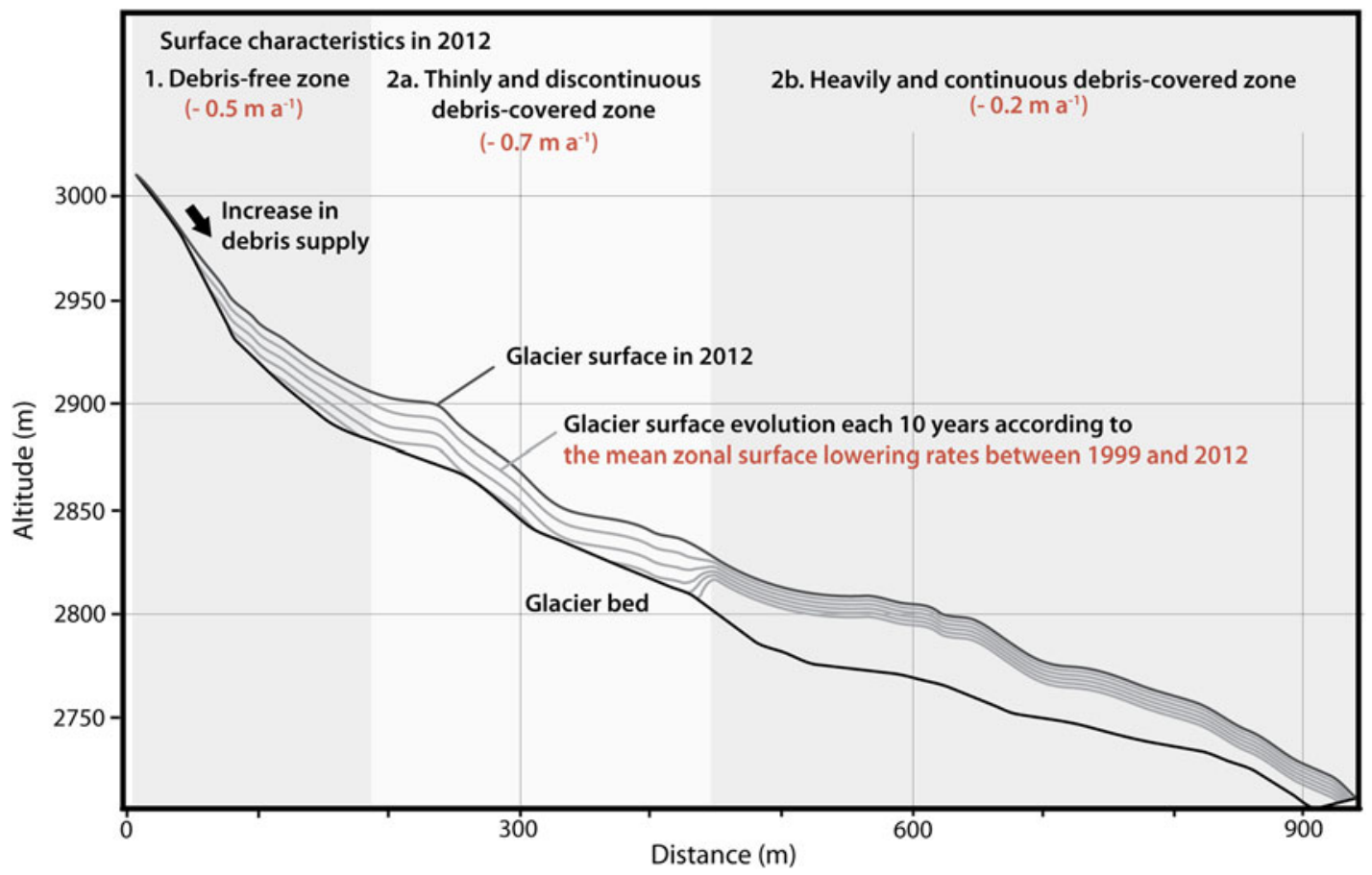

Fig. 10. Evolution model of Tsarmine Glacier for the next few decades. The potential future surface elevation changes have been simply generated using the mean zonal lowering rates between 1999 and 2012.

glaciers under permafrost conditions (e.g. Shroder and others, 2000; Monnier and Kinnard, 2015; Seppi and others, 2015). Bosson and Lambiel (2016) discuss this possible evolution, which seems unlikely, given the probable domination of temperate thermal conditions in the glacier (Kneisel, 2003). However, the integration of glacier ice in the rock glacier during or after the LIA is probable on the northern margin of the Tsarmine Glacier system (Bosson and Lambiel, 2016).

\section{CONCLUSIONS}

Archival aerial photogrammetry, autocorrelation of orthophotos and GPR have been used to study the decadal behaviour of Tsarmine Glacier, a very small heavily debris-covered glacier located in an Alpine permafrost environment.

Spatial and temporal heterogeneity has characterised the glacier dynamics in recent decades. The upper half of the glacier presents the largest elevation changes, which are mainly related to (summer) air temperature variations. The accumulation of snow/ice in the period 1967-1983 and its rapid, almost complete, melt between 1983 and 1999 have induced related significant volume gains and losses. Volume loss has particularly affected the upper central part, where the surface lowering exceeded $30 \mathrm{~m}$ between 1967 and 2012. The consequences of climatic variations have been attenuated on the lower half of the glacier because of its covering under a thick debris layer. While the frontal zone showed several metres of lowering between 1967 and 2012, the lower central zone surface rose by up to $10 \mathrm{~m}$. This was related to the downward transfer of the ice accumulated before 1983 and associated compressive stress. The surface displacement rates have slowed down in recent decades in relation with the glacier thinning. In 2015 , the glacier volume was $4.05 \pm 0.4 \times 10^{6} \mathrm{~m}^{3}$, corresponding to $2 / 3$ of the volume in 1967 . The mean interpolated 2015 glacier thickness was $15 \mathrm{~m}$. In the next few decades, the differential ablation observed at the glacier scale could lead to its separation in two entities: an uppermost shrinking glacier and a lowermost heavily debris-covered dead ice body.

The decadal behaviour of Tsarmine Glacier exhibits particularities in time and space compared with the other local larger glaciers. Until the late 1990s, average geodetic mass balances ranged between 0.30 and $-0.63 \mathrm{~m}$ w.e. $\mathrm{a}^{-1}$. The temporal variation and magnitude of these values were consistent with those measured for other local glaciers, illustrating the dominant control of regional climate. However, Tsarmine has had less negative mass balances than neighbouring glaciers (stabilised above $-0.30 \mathrm{~m}$ w.e. $\mathrm{a}^{-1}$ ) since 1999. The spatial pattern of elevation changes also contrasts with neighbouring glaciers. Whereas Tsarmine was mainly affected by lowering in its upper half, the larger valley glaciers lost most of their mass at their tongues. Both temporal and spatial particularities highlight the limitation of the regional climate control on Tsarmine Glacier. The recent occurrence of this negative feedback is mostly related to the retreat of the debris-free area into a shaded and avalanchefed north-facing niche, whereas the thick debris cover and cold air/ground conditions limit the ablation rate in this permafrost environment.

These results show that the evolution model of larger valley glaciers cannot be transferred 1:1 to very small debris-covered glaciers. Glacier system characteristics may complicate glacier responses to the climate forcing in time and space, and local additional controls generate heterogeneities and non-linearities in dynamics. In that way, studies focusing on complex glacial behaviours have to be thorough and backed up by field surveys. This study also highlights the potential of archival aerial photogrammetry to improve the knowledge on complex glacial dynamics on a decadal timescale. 


\section{ACKNOWLEDGEMENTS}

The first two authors contributed equally to this work. We acknowledge those people who helped during field measurements (especially D. Bonneaux). Hydro-exploitation SA, Alpiq SA and Grande Dixence SA kindly provided the Arolla climate data. This manuscript was improved thanks to the valuable advice and comments of J-M Fallot and N. Deluigi (Uni. Lausanne) and M. Huss (Uni. Fribourg \& ETH Zürich). B. Scott is acknowledged for proofreading the English text.

\section{REFERENCES}

Ackert RPJ (1998) A rock glacier/debris-covered glacier system at Galena Creek, Absaroka Mountains, Wyoming. Geog. Ann. A, 80, 267-276

Arendt A, Walsh J and Harrison W (2009) Changes of glaciers and climate in Northwestern North America during the late twentieth century. J. Clim., 22, 4117-4134 (doi: 10.1175/2009JCLI2784.1)

Begert M, Schlegel T and Kirchhofer W (2005) Homogeneous temperature and precipitation series of Switzerland from 1864 to 2000. Int. J. Climatol., 25(1), 65-80 (doi: 10.1002/joc.4172)

Benn DI, Kirkbride MP, Owen LA and Brazier V (2003) Glaciated valley landsystems. In Evans DJA ed. Glacial landsystems. Arnold, London, 372-406

Benn DI and 9 others (2012) Response of debris-covered glaciers in the Mount Everest region to recent warming, and implication for outburst flood hazards. Earth-Science Rev., 114, 156-174 (doi: 10.1016/j.earscirev.2012.03.008)

Berthling I, Schomacker A and Benediktsson IÖ (2013) The glacial and periglacial research frontier: where from here? In Shroder JF , chief ed., Giardino R and Harbor J eds. Treatise on geomorphology. Academic Press, San Diego, 479-499 (doi: 10.1016/B978-0-12-374739-6.00224-4)

Bingham RG, Hubbard AL, Nienow PW and Sharp MJ (2008) An investigation into the mechanisms controlling seasonal speedup events at a High Arctic glacier. J. Geophys. Res., 113, F02006 (doi: 10.1029/2007JF000832)

Bosson JB and Lambiel C (2016) Internal structure and current evolution of small debris-covered glacier systems located in alpine permafrost environments. Front. Earth Sci., 4, 39 (doi: 10.3389/ feart.2016.00039)

Bosson JB and 6 others (2015) The influence of ground ice distribution on geomorphic dynamics since the Little Ice Age in proglacial areas of two cirque glacier systems. Earth Surf. Proc. Land., 40, 666-680 (doi: 10.1002/esp.3666)

Bouët M (1985) Climat et météorologie de la Suisse romande. Payot, Lausanne

Carrivick JL and 7 others (2015) Decadal-scale changes of the Ödenwinkelkees, Central Austria, suggest increasing control of topography and evolution towards steady state. Geog. Ann. A, 97, 543-562 (doi: 10.1111/geoa.12100)

Carturan L and 10 others (2013a) Area and volume loss of the glaciers in the Ortles-Cevedale group (Eastern Italian Alps): controls and imbalance of the remaining glaciers. Cryosphere, 7, 13391359 (doi: 10.5194/tc-7-1339-2013)

Carturan $L$ and 11 others (2013b) Current behavior and dynamics of the lowermost Italian glacier (Montasio Occidentale, Julian Alps). Geog. Ann. A, 95(1), 79-96 (doi: 10.1111/geoa.12002)

Chandler JH, Lane SN and Walstra J (2007) Quantifying landform change. In Fryer J, Mitchell $\mathrm{H}$ and Chandler $\mathrm{JH}$ eds. Applications of 3D measurement from images. Whittles Publishing, Dunbeath, 139-170

Collins M and 13 others (2013) Long-term climate change: projections, commitments and irreversibility. In Stocker TF and 9 others eds. Climate change 2013: the physical science basis. Contribution of working group I to the fifth assessment report of the intergovernmental panel on climate change. Cambridge University Press, Cambridge, 1029-1136

Colucci RR and Guglielmin M (2014) Precipitation-temperature changes and evolution of a small glacier in the southeastern European Alps during the last 90 years. Int. J. Climatol., 35(10), 2783-2797 (doi: 10.1002/joc.4172)

Copland L and 8 others (2009) Glacier velocities across the central Karakoram. Ann. Glaciol., 50(52), 41-49 (doi: 10.3189/ 172756409789624229)

Cuffey KM and Paterson WSB (2010) The physics of glaciers, 4th edn. Butterworth-Heinemann, Oxford

DeBeer CM and Sharp MJ (2009) Topographic influences on recent changes of very small glaciers in the Monashee Mountains, British Columbia, Canada. J. Glaciol., 55(192), 691-700 (doi: 10.3189/002214309789470851)

Delaloye R (2008) Parois glaciaires... parois rocheuses: l'évolution séculaire des grandes faces alpines. In Rothenbühler $\mathrm{C}$ ed. Klimaveränderungen auf der Spur. Studien des Europäisches Tourismus Instituts an der Academia Engiadina, Samedan, vol. 5, 93-104

Delaloye R and 14 others (2008) Recent interannual variations of rockglaciers creep in the European Alps. In Kane DL and Hinkel KM eds. Proceedings of the 9th international conference on permafrost, 29 June-3 July 2008, Fairbanks, Alaska, vol. 1. Institute of Northern Engineering, Fairbanks, 343-348

Deline P (2005) Change in surface debris cover on Mont Blanc massif glaciers after the "Little Ice Age" termination. Holocene, 15(2), 302-309 (doi: 10.1191/0959683605h1809rr)

Deline P, Gardent M, Magnin F and Ravanel L (2012) The morphodynamics of the Mont Blanc massif in a changing cryosphere: a comprehensive review. Geog. Ann. A, 94, 265-283 (doi: 10.1111/j.1468-0459.2012.00467.x)

Deline $\mathrm{P}$ and 12 others (2015) Ice loss and slope stability in highmountain regions. In Shroder JF, Haeberli W and Whiteman C eds. Snow and ice-related hazards, risks, and disasters. Academic Press, San Diego, 521-561 (doi: 10.1016/B978-0-12394849-6.00015-9)

Diolaiuti GA, Bocchiola D, Vigiasindi M, D'Agata C and Smiraglia C (2012) The 1975-2005 glacier changes in Aosta Valley (Italy) and the relations with climate evolution. Prog. Phys. Geog., 36 (6), 764-785 (doi: 10.1177/0309133312456413)

Etzelmüller B and Hagen JO (2005) Glacier-permafrost interaction in Arctic and alpine mountain environments with examples from southern Norway and Svalbard. In Harris C and Murton JB eds. Cryospheric systems: glaciers and permafrost. Geological Society, London, Special Publications, vol. 242, 11-27 (doi: 10.1144/GSL.SP.2005.242.01.02)

Fischer A (2009) Calculation of glacier volume from sparse ice-thickness data, applied to Schaufelferner, Austria. J. Glaciol., 55(191), 453-460 (doi: 10.3189/002214309788816740)

Fischer A and Kuhn M (2013) Ground-penetrating radar measurements of 64 Austrian glaciers between 1995 and 2010. Ann. Glaciol., 54(64), 179-188 (doi: 10.3189/2013AoG64A108)

Fischer M, Huss M, Barboux C and Hoelzle M (2014) The new Swiss Glacier Inventory SGI2010: relevance of using high-resolution source data in areas dominated by very small glaciers. Arct. Antarct. Alp. Res., 46(4), 933-945 (doi: 10.1657/1938-424646.4.933)

Fischer M, Huss M and Hoelzle M (2015) Surface elevation and mass changes of all Swiss glaciers 1980-2010. Cryosphere, 9, 525-540 (doi: 10.5194/tc-9-525-2015)

Gardner AS and 15 others (2013) A reconciled estimate of glacier contributions to sea level rise: 2003 to 2009. Science, 340 (6134), 852-857 (doi: 10.1126/science.1234532)

Gomez A and 5 others (2003) Talus instability in a recent deglaciation area and its relationship to buried ice and snow cover evolution (Picacho del Veleta, Sierra Nevada, Spain). Geog. Ann. A, 85, 165-182

Gudmundsson GH and 5 others (2000) High-resolution measurements of spatial and temporal variations in surface velocities of 
Unteraargletscher, Bernese Alps, Switzerland. Ann. Glaciol., 31, 63-68

Haeberli W (1985) Global land-ice monitoring: present status and future perspectives. United States Department of Energy, Glaciers, Ice Sheets, and Sea level: Effect of a CO2-Induced Climatic Change. Report DOE/EV 60235-1. National Academy Press, Seattle, WA, 216-231

Haeberli W, Huggel C, Paul F and Zemp M (2013) Glacial responses to climate change. In Shroder JF, chief ed., James LA, Harend CP and Clague JJ eds. Treatise on geomorphology. Academic Press, San Diego, 152-175 (doi: 10.1016/B978-0-12-374739-6.00350-X)

Hubbard B and Glasser NF (2005) Field techniques in glaciology and glacial geomorphology: ice radar. Wiley, Chichester, 148-178

Huss M (2010) Mass balance of Pizolgletscher. Geog. Helvetica, 65 (2), 80-92

Huss M (2012) Extrapolating glacier mass balance to the mountainrange scale: the European Alps 1900-2100. Cryosphere, 6, 713727 (doi: 10.5194/tc-6-713-2012)

Huss M (2013) Density assumptions for converting geodetic glacier volume change to mass change. Cryosphere, 7, 877-887 (doi: 10.5194/tc-7-877-2013)

Huss $M$ and Hock R (2015) A new model for global glacier change and sea-level rise. Front. Earth Sci., 3, 54 (doi: 10.3389/ feart.2015.00054)

Huss M, Dhulst L and Bauder A (2015) New long-term mass balance series for the Swiss Alps. J. Glaciol., 61(227) (doi: 10.3189/ 2015JoG15J015)

Huss M and Fischer M (2016) Sensitivity of very small glaciers in the Swiss Alps to future climate change. Front. Earth Sci., 4(34) (doi: 10.3389/feart.2016.00034)

Iturrizaga L (2013) Bent glacier tongues: a new look at Lliboutry's model of the evolution of the crooked Jatunraju Glacier (Parón Valley, Cordillera Blanca, Perú). Geomorphology, 198, 147162 (doi: 10.1016/ j.geomorph.2013.05.024)

Ivy-Ochs S and 5 others (2009) Latest Pleistocene and Holocene glacier variations in the European Alps. Quat. Sci. Rev., 28, 2137-2149 (doi: 10.1016/j.quascirev.2009.03.009)

Jóhannesson T, Raymond C and Waddington E (1989) Time-scale for adjustment of glacier to changes in mass balance. J. Glaciol., 35 (121), 355-369

Kellerer-Pirklbauer A, Lieb GK, Avian M and Gsurning J (2008) The response of partially debris-covered valley glaciers to climate change: the example of the Pasterze Glacier (Austria) in the period 1964 to 2006. Geog. Ann. A, 90(4), 269-285 (doi: 10.1111/j.1468-0459.2008.00345.x)

Kirkbride MP and Deline P (2013) The formation of supraglacial debris covers by primary dispersal from transverse englacial debris bands. Earth Surf. Proc. Land., 15(38), 1779-1792 (doi: 10.1002/esp.3416)

Kneisel C (2003) Permafrost in recently deglaciated glacier forefields measurements and observations in the eastern Swiss Alps and northern Sweden. Z. Geomorph. N. F., 47(3), 289-305

Kneisel C and Kääb A (2007) Mountain permafrost dynamics within a recently exposed glacier forefield inferred by a combined geomorphological, geophysical and photogrammetrical approach. Earth Surf. Proc. Land., 32, 1797-1810 (doi: 10.1002/esp.1488)

Kuhn M (1995) The mass balance of very small glaciers. Z. Gletscherkd. Glazialgeol., 31(1-2), 171-179

Lambiel C, Reynard E, Cheseaux G and Lugon R (2004) Distribution du pergélisol dans un versant instable, le cas de Tsarmine (Arolla, Evolène, Vs). Bull. Murithienne, 122, 89-102

Lane SN, Westaway RM and Hicks DM (2003) Estimation of erosion and deposition volumes in a large, gravel-bed, braided river using synoptic remote sensing. Earth Surf. Proc. Land., 28(3), 249-271

Lilleøren KS and 5 others (2013) The distribution, thermal characteristics and dynamics of permafrost in Tröllaskagi, Northern Iceland, as inferred from the distribution of rock glaciers and ice-cored moraines. Permafrost Periglac. Process, 24, 322-335 (doi: 10.1002/ppp.1792)
López-Moreno JI, Nogués-Bravo D, Chueca.Cía J and JuliánAndrés A (2006) Change of topographic control on the extent of cirque glaciers since the Little Ice Age. Geophys. Res. Let., 33, L24505 (doi: 10.1029/2006GL028204)

López-Moreno JI and 10 others (2015) Accelerate wastage of the Monte Perdido Glacier in the Spanish Pyrenees during recent stationary climatic conditions. Cryosphere Disc., 9, 5021-5051 (doi: 10.5194/tcd-9-5021-2015)

Mayer C, Lambrecht A, Belò M, Smiraglia C and Diolaiuti G (2006) Glaciological characteristics of the ablation zone of Baltoro glacier, Karakorum, Pakistan. Ann. Glaciol., 43, 123-131

Micheletti N, Lambiel C and Lane SN (2015a) Investigating decadal scale geomorphic dynamics in an Alpine mountain setting. J. Geophys. Res., 120(10) (doi: 10.1002/2015JF003656)

Micheletti N, Lane SN and Chandler JH (2015b) Application of archival aerial photogrammetry to quantify climate forcing of alpine landscapes. Photogram. Rec., 30, 143-165 (doi: 10.1111/ phor.12099)

Monnier S and Kinnard C (2015) Reconsidering the glacier to rock glacier transformation problem: new insights from the central Andes of Chile. Geomorphology, 238, 47-55 (doi: 10.1016/j. geomorph.2015.02.025)

Müller F, Caflish T and Müller G (1976) Firn und Eis des Schweizer Alpen: Glescherinventar. No. 57, Geographisches Institut der ETH Zürich, Zürich

Paasche $\varnothing$ (2012) Cirque glaciers. In Singh VP, Singh P and Haritashya UK eds. Encyclopedia of snow, ice and glaciers. Springer, Dordrecht

Paul F, Kääb A and Haeberli W (2007) Recent glacier changes in the Alps observed by satellite: consequences for future monitoring strategies. Glob. Planet. Ch., 56, 111-122 (doi: 10.1016/j. gloplacha.2006.07.007)

Pellicciotti F and 5 others (2015) Mass-balance changes of the debris-covered glaciers in the Langtang Himal, Nepal, from 1974 to 1999. J. Glaciol., 226(61), 373-386 (doi: 10.3189/ 2015JoG13J237)

Pfeffer WT and 19 others 8(2014) The Randolph Glacier Inventory: a globally complete inventory of glaciers. J. Glaciol., 221(60), 537552 (doi: 10.3189/2014JoG13J176)

Pourrier J, Jourde H, Kinnard C, Gascoin S and Monnier S (2014) Glacier meltwater flow paths and storage in a geomorphologically complex glacial foreland: the case of the Tapado glacier, dry Andes of Chile $\left(30^{\circ} \mathrm{S}\right)$. J Hydrol., 519, 1068-1083 (doi: 10.1016/j.jhydrol.2014.08.023)

Radić V and 5 others (2014) Regional and global projections of twenty-first century glacier mass changes in response to climate scenarios from global climate models. Clim. Dyn., 42(1-2), 3758 (doi: 10.1007/s00382-013-1719-7)

Reynard E and 7 others (2003) Glacier/permafrost relationships in forefields of small glaciers (Swiss Alps). In Phillips $M$, Springman SM and Arenson LU eds. Proceedings of the 8th international conference on permafrost, vol. 1. Swets \& Zeitlinger: Lisse, Zurich, 947-952

Ribolini A and 7 others (2010) The internal structure of rock glaciers and recently deglaciated slopes as revealed by geoelectrical tomography: insights on permafrost and recent glacial evolution in the Central and Western Alps (Italy-France). Quat. Sci. Rev., 29, 507-521 (doi: 10.1016/j.quascirev.2009.10.008)

Scherler D, Bookhagen B and Strecker MR (2011) Spatially variable response of Himalayan glaciers to climate change affected by debris cover. Nat. Geosci., 4, 156-159 (doi: 10.1038/ NGEO1068)

Schmidt S and Nüsser M (2009) Fluctuations of Raikot Glacier during the past 70 years: a case study from the Nanga Parbat massif, northern Pakistan. J. Glaciol., 194(55), 949-959 (doi: 10.3189/002214309790794878)

Scotti R, Brardinoni F and Crosta GB (2014) Post-LIA glacier changes along a latitudinal transect in the Central Italian Alps. Cryosphere, 8, 2235-2252 (doi: 10.5194/tc-8-2235-2014) 
Seppi R and 8 others (2015) Current transition from glacial to periglacial processes in the Dolomites (South-Eastern Alps). Geomorphology, 228, 71-86 (doi: 10.1016/j.geomorph. 2014.08.025)

Serrano E, González-Trueba JJ, Sanjosé JJ and Del Rìo LM (2011) Ice patch origin, evolution and dynamics in a temperate high mountain environment: the Jou Negro, Picos de Europa (NW Spain). Geog. Ann. A, 93, 57-70 (doi: 10.1111/j.1468-0459.2011. 00006x)

Shea JM, Immerzeel WW, Wagnon P, Vincent C and Bajracharya S (2015) Modelling glacier change in the Everest region, Nepal Himalaya. Cryosphere, 9, 1105-1128 (doi: 10.5194/tc-9-11052015)

Shroder JF, Bishop MP, Copland L and Sloan VF (2000) Debriscovered glaciers and rock glaciers in the Nanga Parbat Himalaya, Pakistan. Geog. Ann. A, 82(1), 17-31

Small RJ (1983) Lateral moraines of glacier de Tsijiore Nouve: form, development, and implications. J. Glaciol., 29(102), 250-259

Sold $L$ and 5 others (2013) Methodological approaches to infer endof-winter snow distribution on alpine glaciers. J. Glaciol., 59 (218), 1047-1059 (doi: 10.3189/2013JoG13J015)
Thibert E, Eckert N and Vincent C (2013) Climatic drivers of seasonal glacier mass balances: an analysis of 6 decades at Glacier de Sarennes (French Alps). Cryosphere, 7, 47-66 (doi: 10.5194/tc7-47-2013)

Thomson MH, Kirkbride MP and Brock BW (2000) Twentieth century surface elevation change of the Miage Glacier, Italian Alps. In Nakawo M, Raymond CF and Fountain A eds. Debris-covered glaciers, vol. 264. IAHS Publication, Seattle, 219-225

Vacher P, Dumoulin S, Morestin F and Mguil-Touchal S (1999) Bidimensional strain measurement using digital images. Proc. Inst. Mech. Eng., 213(8), 811-817

Vaughan DG and 13 others (2013) Observations: cryosphere. In Stocker TF and 9 others eds. Climate change 2013: the physical science basis. Contribution of working group I to the fifth assessment report of the intergovernmental panel on climate change. Cambridge University Press, Cambridge, 317-382

Walstra J, Chandler JH, Dixon N and Dijkstra TA (2004) Extracting landslide movements from historical aerial photographs. In Lacerda W, Erlich M, Fontoura SAB and Sayao ASF eds. Landslides: evaluation and stabilization. Taylor \& Francis, London, 843-850

MS received 5 October 2015 and accepted in revised form 25 March 2016; first published online 26 April 2016 